\title{
Fossils from the
}

Eutaw Formation

Chattahoochee River

\section{Region, Alabama-Georgia}

GEOLOGIGAL SURVEY PROFESSIONAL PAPER 274-J 


\section{Fossils from the}

\section{Eutaw Formation}

Chattahoochee River

Region, Alabama-Georgia

$B y$ LLOYD WILLIAM STEPHENSON

A SHORTER CONTRIBUTION TO GENERAL GEOLOGY

GEOLOGICAL SURVEY PROFESIONAL PAPER 274-J

Descriptions and illustrations

of Late Cretaceous pelecypods

and one ammonite

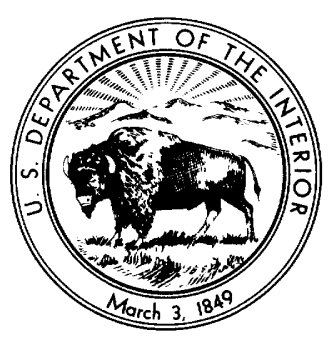

UNITED STATES GOVERNMENT PRINTING OFFICE, WASHINGTON : 1956 


\section{UNITED STATES DEPARTMENT OF THE INTERIOR \\ Fred A. Seaton, Secretary \\ GEOLOGICAL SURVEY \\ Thomas B. Nolan, Director}

For sale by the Superintendent of Documents, U. S. Government Printing Office Washington 25, D. C. - Price 70 cents (paper cover) 


\section{CONTENTS}

Abstract

Stratigraphic setting

Eutaw localities in east-central Alabama and adjacent

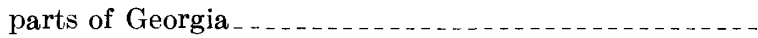

Chattahoochee River............................

Chattahoochee County, Ga., east of Chattahoochee

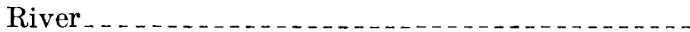
Russell County, Ala., west of Chattahoochee River.

Macon County, Ala............................

The Eutaw fauna and its relationships..............

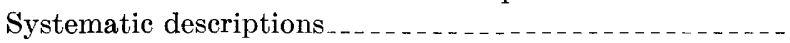

Mollusca................

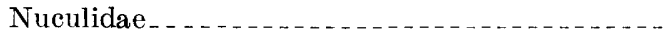

\begin{tabular}{|c|c|c|}
\hline $\begin{array}{r}\text { Page } \\
227\end{array}$ & Systematic descriptions-Continued & \\
\hline 227 & Mollusca-Continued & Page. \\
\hline 227 & Arcidae & 235 \\
\hline 228 & Pteriidae $_{\ldots} \ldots$ & 237 \\
\hline 228 & Ostreidae ........ & 238 \\
\hline 228 & Anomiidae & 242 \\
\hline & Cardiidae & 242 \\
\hline 230 & Veneridae & 243 \\
\hline 231 & Mactridae $\ldots \ldots$ & 244 \\
\hline 233 & Corbulidae............ & 244 \\
\hline $\begin{array}{l}234 \\
234\end{array}$ & Placenticeratidae & 247 \\
\hline 234 & References. & 248 \\
\hline 234 & ${ }_{\text {Index }}$ & 249 \\
\hline
\end{tabular}

\section{ILLUSTRATIONS}

[Plates follow page 250]

Plate 38. Viaws of the Eutaw formation in the Chattahoochee region.

39. Nucula, Breviarca, and Protarca.

40. Breviarca, Trigonarca, Pseudoptera, and Ostrea.

41. Cardium (Trachycardium), Gryphaea, Anomia, and Pseudoptera.

42. Ostrea cretacea Morton.

43. Ostrea (Lopha) and Exogyra.

44. Cymbophora, Caryocorbula, Legumen, and Placenticeras.

45. Corbula and Placenticeras.

FigURE 30. Sketch map of parts of Russell County, Ala. and Chattahoochee and Muskogee Counties, Ga., showing fossilbearing localities.

Page 

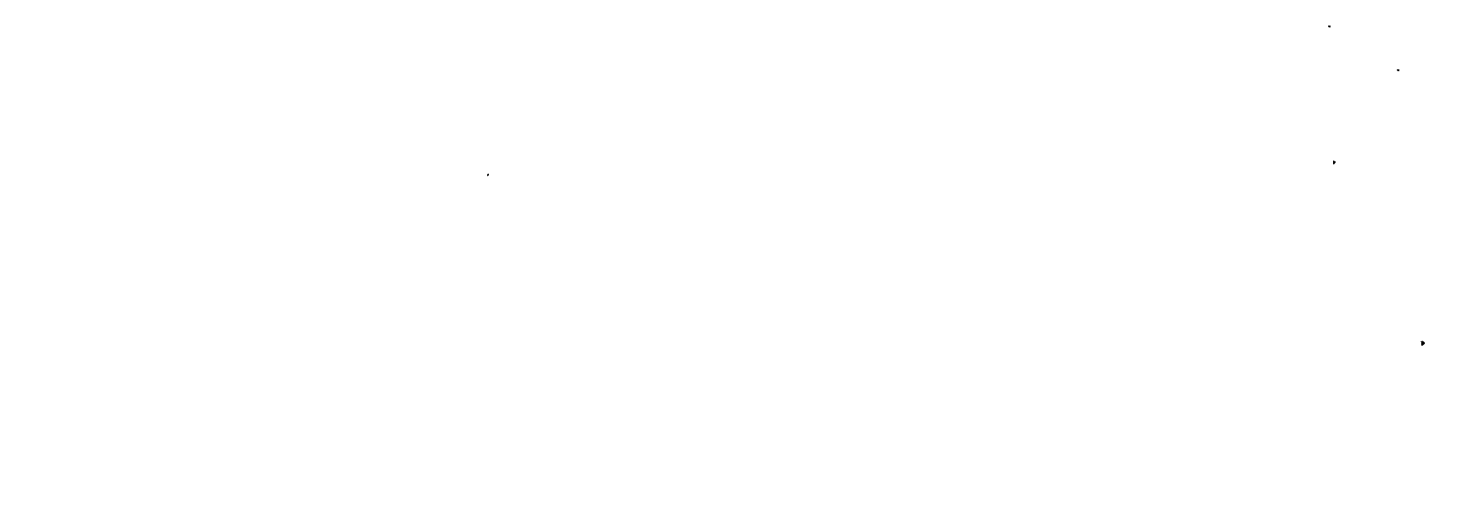


\title{
A SHORTER CONTRIBUTION TO GENERAL GEOLOGY
}

\section{FOSSILS FROM THE EUTAW FORMATION, GHATTAHOOGHEE RIVER REGION, ALABAMA-GEORGIA}

\author{
By Lloyd William Stephenson
}

\begin{abstract}
The Eutaw formation in east-central Alabama and an adjacent area in west-central Georgia has yielded an assemblage of fossil mollusks, some of the species of which are restricted to that unit and are of value in determining the age and stratigraphic relationships of the Upper Cretaceous formations in the Chattahoochee River region. Several of the restricted species have close relatives in younger formations in the Atlantic and Gulf Coastal Plain. Representative species are described in this paper.

The Eutaw formation is estimated to be about 200 feet thick in the Chattahoochee River region; it consists mainly of more or less argillaceous and micaceous sand with interbedded layers of calcareous sandstone and concretions, but includes some important layers and lenses of shale. These sediments were deposited in relatively shallow marine offshore waters. As a conspicuous part of their faunal content, certain layers contain vast numbers of the shells of Ostrea cretacea Morton that are either scattered through the matrix or are so abundant in some beds as to form almost solid oyster reefs.

Of the 16 species and 1 variety described, 10 species and the variety are new. All are bivalves except one, which is an ammonite. The described species are:

Nucula prepercrassa Stephenson, n. sp.

$\dagger^{*}$ Protarca obliqua Stephenson

*Breviarca symmetros Stephenson, n. sp.

$\dagger^{*}$ Trigonarca inflata Stephenson, n. sp.

Pseudoptera securiformis Stephenson, n. sp.

Ostrea (Lopha) ucheensis Stephenson, n. sp. cretacea Morton

Gryphaea wratheri Stephenson

Exogyra upatoiensis Stephenso_

$\dagger^{*}$ Anomıa preolmstedi Stephenson, n. sp.

${ }^{*}$ Cardium (Trachycardium) ochilleanum Stephenson, n. sp.

$\dagger^{*}$ Legumen aff. L. carolinense (Cor:rad)

*Cymbophora ochilleana Stephenson, n. sp.

$\dagger^{*}$ Caryocorbula? veatchi Stephenson, n. sp. georgiana Stephenson, n. sp.

longa Stephenson, n. var.

Placenticeras benningi Stephenson, n. sp.

Forms marked with an asterisk in the above list are either identical with, or closely allied to, species in the Snow Hill marl member of the Black Creek formation of North Carolina and South Carolina. Five species marked with a dagger have identical or closely related representatives in the Cusseta sand in the Chattahoochee River region. It may be accepted that the indicated species are ancestral to species occurring in the strati-
\end{abstract}

graphically younger Snow Hill marl member and in the Cusseta sand.

The presence of Gryphaea wratheri in the upper part of the Eutaw formation affords satisfactory evidence that the formation is synchronous with the upper part of the Austin chalk of Texas, which includes a zone of $G$. wratheri. The accepted Santonian age of the upper part of the Austin chalk of Texas carries with it the implication that the Eutaw of the eastern Gulf region is also of Santonian age.

\section{INTRODUCTION}

The type area of the Eutaw formation is in the vicinity of Eutaw, the county seat of Greene County in west-central Alabama. As at present classified (Monroe, Conant, Eargle, 1946, p. 204-210), the Eutaw formation in central and western Alabama consists of 160 to 240 feet of marine sediments, including interbedded glauconitic sands and clays in its lower part and mainly massive glauconitic sand, the Tombigbee sand member, in its upper part. There is no sharp line of separation between these two parts. Fossils are rare in the lower part and common in the Tombigbee sand member, especially so in its upper part.

The Eutaw formation of west-central Alabama is unconformably underlain by the McShan formation , which consists of about 200 feet of crossbedded, fine- to medium-grained marine sand that is characterized by its content of fine pale green, partly leached glauconite grains; this unit was formerly considered a part of the overlying Eutaw formation. The Eutaw formation of central and west-central Alabama is unconformably overlain by the Mooreville chalk, the lowermost formation of the Selma group of Alabama and Mississippi.

Traced eastward the McShan formation disappears not far west of the longitude of Montgomery, where presumably it is covered by a transgressive overlap of the Eutaw formation. From Montgomery County eastward the Eutaw formation appears at the surface in an easily traceable belt 4 to 12 miles wide to and beyond the Chattahoochee River. Throughout this 
distance the formation is uncorformably underlain by an undifferentiated unit of the Tuscaloosa group, presumably the Gordo formation. From Montgomery County eastward to the longitude of Hardaway in Macon County, the Eutaw formation is unconformably overlain by the Moorevi!le chalk of the Selma group; east of Hardaway to, and beyond, the Chattahoochee River the overlying unconformable unit is a more or less argillaceous and calcareous sand facies of the Mooreville unit, to which the name Blufftown formation has been given (Veatch, 1909, p. 82-90; Monroe, 1941, p. 73-88).

In its eastward extension from Montgomery County the Eutaw formation has not been satisfactorily divided into a lower and an upper part corresponding to the two parts recognized in central and western Alabama; there is some reason to believe that the lower part of the formation is wanting and that the beds that are present belong mainly to the Tombigbee sand member. In the Chattahoochee region fossiliferous zones occur at different stratigraphic positions in the formation from near its base to its top.

Selected localities that afford exposures of the Eutow and associated formations in the Chattahoochee region were visited by Norman F. Sohl and me in March 1955, and supplementary collections of fossils were made. Through the courtesy of Maj. Gen. Joseph H. Harper and his subordinate officers, and especially by the personal guidance of Capt. J. F. Rast, we were able to visit several important localities in the Fort Benning Military Reservation.

The evolution of our knowledge of the Upper Cretaceous section of eastern Alabama is recorded in many papers, the more important of which are the following: T. A. Conrad (1860, p. 275-298); D. W. Langdon (1890, p. 587-606); S. W. McCallie (1903, p. 199-202); Otto Veatch (1909, esp. p. 82-106); L. W. Stephenson (1911, p. 66-215); L. W. Stephenson $(1914,77$ p.); L. W. Stephenson and W. H. Monroe (1938, p. 1639-1657); Monroe (1941, 150 p.); Monroe (1947, p. 1817-1824); and D. H. Eargle (1950, preliminary map 105, with text).

\section{STRATIGRAPHIC SETTING}

The Eutaw formation of eastern Alabama and western Georgia has not been studied in detail. However, sections have been examined and fossils collected at localities along the belt of outcrop and the contacts of the unit with underlying and overlying formations have been seen at several places. The unit is unconformably underlain by sediments considered by Monroe $(1947$, p. 1,820$)$ to be the eastward continuation of the Gordo formation of the Tuscaloosa group, and is unconformably overlain by the Mooreville chalk (of the
Selma group) and by the Blufftown formation, an eastern sand and clay facies of the Mooreville chalk.

Although the boundaries of the Eutaw formation in Macon and Russell Counties, Ala. and in Chattahoochee County, Ga., have not been mapped in detail the approximate belt of outcrop in the Alabama counties is shown on a map prepared by Monroe (1941, pl. 1) and the important localities on Chattahoochee River and in Chattahoochee County, Ga., are shown on an accompanying sketch map (fig. 30).

The Eutaw formation is estimated to be about 200 feet thick in the Chattahoochee River valley where it is divisible into two parts that do not correspond to the two parts recognized in central and western Alabama. The lower part consists mainly of 130 feet or more of massive marine sand, indurated in certain layers, and containing in some layers vast numbers of the shells of Ostrea cretacea Morton. For convenience of reference this part of the formation is here designated the $O$. cretacea zone. This zone is believed to be approximately synchronous with the Tombigbee sand member of the Eutaw formation of central and western Alabama. The upper part of the formation is greenishgray somewhat laminated clay with subordinate sand, probably attaining a thickness of 50 or more feet; the best exposure of this clay section is at Slick Bluff on Chattahoochee River 2 miles southeast of Fort Mitchell, Russell County. The clay contains the imprints of fossils. Whether this clay forms a persistent unit in the upper part of the Tombigbee sand member, or is present only as one or more lenses of local extent, has not been determined. However, the clay is recognizable above the 0 . cretacea zone for at least 7 or 8 miles west of the exposures on Chattahoochee River (see p. 232). This clay unit may be stratigraphically a little higher and younger than the main body of the Tombigbee sand in central and western Alabama where presumably it is overlapped and concealed by the transgressing Mooreville chalk.

\section{EUTAW LOCALITIES IN EAST-CENTRAL ALABAMA AND ADJACENT PARTS OF GEORGIA}

Descriptions of a few selected localities in Macon and Russell Counties, Ala., and in Chattahoochee County, Ga., that show the character and stratigraphic relationships of the Eutaw formation, and the zonal distribution of its fossils, are given below.

\section{CHATTAHOOCHEE RIVER}

Outcrops in the bluffs and banks of Chattahoochee River, where the belt of outcrop of the Eutaw formation intersects that stream, reveal the character of the strata forming the basal 28 and the upper 50 feet or more of the formation; some of the intervening beds 


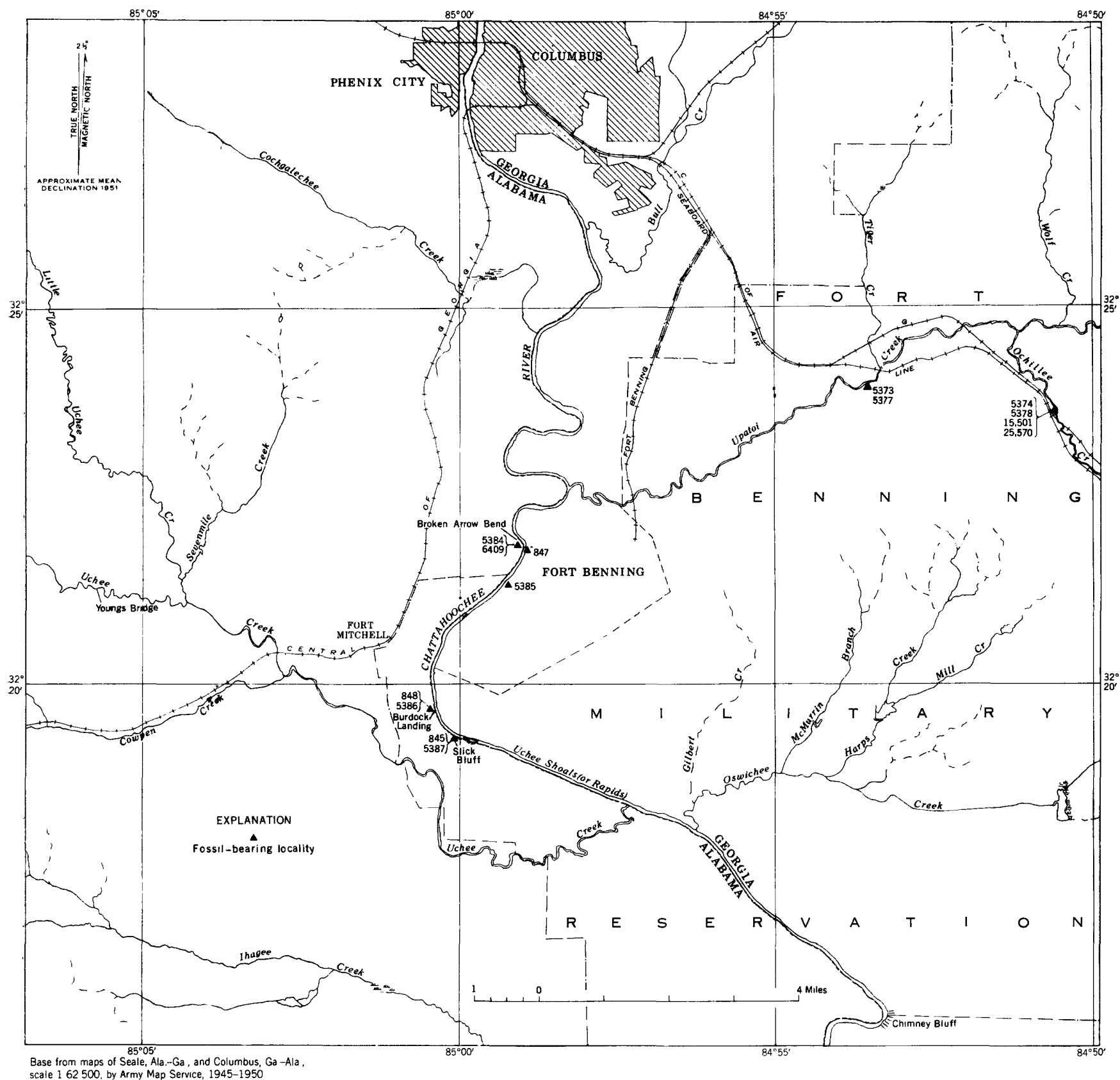

Fifure 30.-Sketeh map of parts of Russell County, Ala. and Muskogee and Chattahoochee Counties, Ga., showing fossil-bearing localities. Numbers are the collection numbers of the United States Geological Survey; each collection made at a given locality bears a separate collection number.

appear in small exposures in the river banks. The first exposure of the formation is in a low bluff on the Georgia side below the mouth of Upatoi Creek, 8.5 miles by the river below Columbus, and the last exposure is in a bluff on the Alabama side, 200 yards above the mouth of Uchee Creek, 16.5 miles below Columbus.

An account of these exposures has been given by Stephenson (1911, p. 82, 83, 117-121). In present usage the Eutaw formation is restricted to the strata exposed along the river between the points indicated in the preceding paragraph.
Between the mouth of Uchee Creek and Chimney Bluff on the east side of the river 22 miles below Columbus no exposures that show the contact between the Eutaw and overlying Blufftown formations were observed. The lower 25 feet of strata exposed at Chimney Bluff consists of irregularly bedded, crossbedded lignitic sand and clav that is interpreted to be referable to the lower part of the Blufftown formation.

The most important Eutaw fossil-bearing strata exposed along the river are those at Broken Arrow Bend, old Burdock Landing, and Slick Bluff. The strata com- 
posing the Eutaw formation in the Chattahoochee area dip gently to the south at an inclination probably not exceeding 30 or 35 feet to the mile.

Section at Broken Arrow Bend.-At Broken Arrow Bend about 10 miles by the river (airline 6 miles) downstream from Columbus, Ga., exposures along the right and left banks of Chattahoochee River show that the contact of the Eutaw formation with the underlying Gordo formation of the Tuscaloosa group is a broadly undulating unconformity. The Gordo consists of coarse, compact, crossbedded, arkosic and micaceous sand and interbedded light-drab to almost white clay. The thickness above water level as seen along the left bank at a medium low stage of the river is 4 or 5 feet and the upper eroded surface rises and falls through a vertical range of 5 feet or more, in places passing below water level and reappearing again farther downstream. The basal 2 to 8 feet or more of the overlying Eutaw formation consists of medium to coarse crossbedded sand and interbedded laminated clay. These materials contain lignitized and silicified wood, including large logs, and poorly preserved fossil leaves. These basal beds are conformably overlain by 15 feet or more of slightly laminated gray micaceous, calcareous sand and clay including interbedded layers of calcareous concretionary nodules 2 or 3 feet apart; these beds dip gently downstream.

The calcareous beds at Broken Arrow Bend contain a late Cretaceous marine fauna, the species of which have been only partly identified and described. Among the forms present are: Pseudoptera securiformis Stephenson, Ostrea cretacea Morton, Exogyra upatoiensis Stephenson, Anomia preolmstedi Stephenson, Legumen cf. L. carolinensis (Conrad), Caryocorbula? veatchi Stephenson and Placenticeras benningi Stephenson (USGS colls. 847, 5384, 6409).

Half a mile downstream from Broken Arrow Bend the layers of nodular limestone dip down to water level and between two of these indurated beds is a layer made up largely of the shells of Ostrea cretacea Morton (large variety) (USGS 5385). From here downstream for the next 2 miles a few low outcrops in the river banks reveal the gently southward dipping indurated beds that characterize the zone of $O$. cretacea, which is estimated to be between 75 and 100 feet thick in this area. More complete exposures of the 0 . cretacea zone, as it is developed west of Chattahoochee River in Russell and Macon Counties, Ala., are described on following pages.

Section at old Burdock Landing.-The upstream end of Uchee Shoals (or Rapids) is at a point on the river about east of Fort Mitchell, and the shoals extend from there for several miles down the river. The submerged indurated layers of the Ostrea cretacea zone of the Eutaw formation are the cause of the shoals. The site of old Burdock Landing is on the Alabama side about threefourths of a mile below the upstream end of the shoals. An exposure just below the landing reveals 30 feet of greenish-gray clay, laminated in part, with fine sand partings. From a fossiliferous bed at the water's edge a short distance below the landing the following forms are identified: Pseudoptera securiformis Stephenson, Ostrea cretacea Morton, O. (Lopha) ucheensis Stephenson, Anomia preolmstedi Stephenson, Cyprimeria cf. $C$. depressa Conrad, Legumen aff $L$. carolinense (Conrad), and Caryocorbula? georgiana Stephenson? (USGS colls. 848 and 5386). These fossils are mainly in the form of prints in finely micaceous clay, but 0 . cretacea Morton is preserved as shells in dark-gray argillaceous, finely micaceous sand.

Section at Slick Bluff.-Slick Bluff is half a mile downstream from old Burdock Landing. The bluff exposes greenish-gray clay that has been considerably disturbed by relatively recent landslides and at some earlier time was affected by earth movements that produced sand-filled fissures, now appearing as socalled sandstone dikes; these dikes were first described by S. W. McCallie (1903, p. 199-202). On account of the disturbed condition of the clay, the section could not be measured but the thickness was estimated to be 50 feet or more. A few fossil prints were collected from the disturbed clay among which were recognized: Ostrea ucheensis Stephenson, Cyprimeria cf. C. depressa Conrad, Legumen aff. L. carolinensis (Conrad), and Caryocorbula? georgiana Stephenson? (USGS colls 845, 5387). The clay section at Slick Bluff overlies the calcareous beds ( $=0$. cretacea zone) and forms the upper part of the Eutaw formation as here interpreted.

Section near mouth of Uchee Creek.-Cretaceous sedimentary rocks interpreted to lie close to the uppermost part of the Eutaw formation are exposed in the right bank of the river about 200 feet upstream from the mouth of Uchee Creek. These beds consist of 25 feet of thinly laminated sand and clay with seams of finely comminuted vegetable matter; the sand is white or stained yellow and is very fine and micaceous; the clay is dark gray. The Cretaceous beds are unconformably overlain by 10 feet of terrace gravel, sand, and loam (Pleistocene).

\section{CHATTAHOOCHEE COUNTY, GA., EAST OF CHATTAHOOCHEE RIVER}

Section on Upatoi Creek.-A bluff on Upatoi Creek 7 miles woutheast of Columbus, Ga., formerly (1908) exposed the section described below; the section is now largely concealed by vegetation. 
Section on Upatoi Creek one-fourth mile below the old ColumbusCusseta road crossing, 7 miles southeast of Columbus

Eutaw formation: Feet

Sand, marine, weathered brown, unconsolidated_.. 5 Sand, fine, and clay, partly weathered, greenishgray, irregularly foliated.......

Sandstone, fine-grained, white ............... 1

Sand, fine, and clay, greenish-gray, irregularly foliated............................

Sand, argillaceous, dark greenish-gray _.......... 5

Sandstone, fine-grained, white.

Clay, with irregular dark clay foliations, and lignite fragments; includes discontinuous nodular limestone layers and irregularly distributed calcareous concretions; fossiliferous...................... 25

Unconformity, contact poorly exposed.

Tuscaloosa group (Gordo formation):

Sand, coarse, arkosic, crossbedded, light-gray streaked with yellow; includes subordinate layers of sandy clay ........... 22

Concealed to water level................... $21 \pm$

$871 / 2 \pm$

Fossils described in this paper from the basal 25 feet of the Eutaw formation at the preceding locality are listed below.

Fossils from the basal 25 feet of the Eutaw formation on Upatoi Creek, 7 miles southeast of Columbus, Ga. (USGS 5373 and 5877)

Pseudoptera securiformis Stephenson

Ostrea cretacea Morton

Exogyra upatoiensis Stephenson

Legumen aff. L. carolinense (Conrad)

Placenticeras benningi Stephenson

Additional fossils, mostly poorly preserved, belonging to the following genera, have been identified from the Upatoi Creek locality: Trigonarca, Pholadomya, Cardium, Tellina?, Turritella, Anchura, and Volutomorpha. Several species of shark teeth are present.

Section on Ochillee Creek.-Strata corresponding to the basal 25 feet of the Eutaw formation in the section on Upatoi Creek are exposed on Ochillee Creek at and near the site of the dam and the old mill at Ochillee, Chattahoochee County, and for several hundred yards both downstream and upstream from the dam site. The bridge of the present roadway is approximately at the site of the dam and mill. These beds are fossiliferous and include some fossils that are in a more complete state of preservation than those found at other Eutaw localities in the Chattahoochee area. A list of the species described from Ochillee Creek is given below.
Fossils from the basal 20-25 feet of the Eutaw formation on Ochillee. Creek near old Ochillee, Chattahoochee. County (USGS 5874, 5878, 15501, and 255\%0)

Protarca obliqua Stephenson

Pseudoptera securiformis Stephenson

Ostrea cretacea Morton

Anomia preolmstedi Stephenson

Legumen aff. L. carolinense (Conrad)

Cymbophora ochilleana Stephenson

Caryocorbula? veatchi Stephenson

Placenticeras benningi Stephenson

In addition to the species formally described in this paper, fossils belonging to the following genera have been recognized in the collections from Ochillee: Serpula (tubes), Idonearca, Pecten (Camptonectes), Etea, Cyprimeria, Leptosolen, Turritella, and Anchura.

Both the dam and the water mill of former years. have completely disappeared from the Ochillee locality. Upstream from the site of the dam there is now exposed in the bed of the creek marine argillaceous sand with irregularly distributed ovate concretions 4 to 8 inches. in diameter; these concretions contain imprints and molds of fossils with films of adhering shell substance, among which are many individuals of Pseudoptera securiformis Stephenson and Placenticeras benningi Stephenson (USGS 25570).

\section{RUSSELL COUNTY, ALA., WEST OF CHATTAHOOCHEE RIVER}

Section 4 miles southwest of Phenix City.-The unconformable contact between the Gordo formation of the Tuscaloosa group and the overlying Eutaw formation was formerly well exposed on the old Columbus-Seale road 4 miles southwest of Phenix City (opposite Columbus); at this locality the contact is gently and broadly undulating. This locality was described in earlier papers (Stephenson, 1911, p. 74, 75, pl. 6-B; 1914, p. 10, 11, pl. 1-B). The Gordo formation of this paper is the same as the Lower Cretaceous of the earlier papers. The earlier correlation of this unit with the Lower Cretaceous seemed to have found partial confirmation in E. W. Berry's interpretation (oral communication) of a meager, poorly preserved fossil flora found at old Fort Decatur in Macon County, Ala. (Stephenson, 1914, p. 12). Additional plant remains collected from the same place at a later date caused Berry (1923, p. 433-435) to change his mind and refer the plants to the Upper Cretaceous, a correlation that. is in agreement with the conclusions of more recent. investigators. 
Section southwest of Youngs Bridge.-An exposure in a cut of U. S. Highway 431, on the northeastwardfacing slope of Uchee Creek valley 0.6 mile southwest of Youngs Bridge, reveals the following section:

Section in cut of $U$. S. Highway 431, on the northeastward-facing slope of Uchee Creek valley in $S W^{1 / 4} N W^{1} / 4$ sec. 26, T. $16 N$., R. 29 E., Russell County, Ala.

Eutaw formation:

Shale, gray, marine, with interbedded thin layers of light-gray sandstone in upper 15 feet, cut by 2 nearly vertical sandstone dikes; a soft sandstone bed about 18 feet above base contains Inoceramus sp., Liopistha sp., and Placenticeras benningi Stephenson? (USGS 25462)

Sandstone, calcareous; contains many shells of Ostrea cretacea Morton.

\section{Feet}

Section along the old Marvyn road $25 / 8$ miles (airline) north by west of Uchee, near center of sec. 7, T. 16 N., R. 27 E., on northeastward-facing slope of a headwater branch of a small tributary of Uchee Creek, Russell County, Ala.

Blufftown formation(?):

Eutaw formation:

about 2.5 feet thick 8 feet below top

Sand, greenish-gray massive, marine, with two interbedded whitish indurated layers, about..........

Conglomeratic sand; includes quartz and phosphatic pebbles, many fragments of dark bones, and waterworn shells; also many medium-sized shells of a smooth Exogyra, and some large shells of Trigonarca, Cardium, and other forms . . . . . . Unconformity.

Eutaw formation:

Sand, gray compact argillaceous, micaceous _........

Sand, darker gray than the preceding; contains many shell fragments, mainly in the upper half, and some well-preserved shells, mostly small but including a few of medium size; included among the fossils are: Trigonarca inflata Stephenson, Exogyra sp. (medium size, smooth), Cyprimeria sp. (small), and Caryocorbula? veatchi longa Stephenson

A cut on the same highway, 0.15 mile to the north (downslope) from the preceding cut, 5.75 miles south of Lee County line, reveals an 18-foot section of marine sand, clay, and marl. A layer of coquinalike marl 4 to 6 feet above the base contains many shells of
20. Sand, light-red, chert and quartz grains as much as one-fourth inch long, subangular, poorly sorted; weathered to colluvium in upper part .. 23

19. Sand, red and gray, fine, with thin laminae of gray

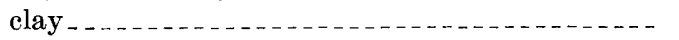

18. Sand, gray and yellow, fine, clayey, ferruginous, micaceous; contains prints of fossils

17. Sand, light-brown, fine, much more clayey than overlying bed; contains many prints of fossils, those in lower 2 feet retaining some white

calcium carbonate
16. Sandstone, hard, fine-grained; base and top slightly irregular; contains many shells of Ostrea cretacea Morton, and some of Anomia preolmstedi Steph-

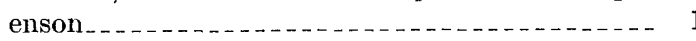

15. Sand, light-brown, clayey, like bed 17 above; contains many shells of 0 . cretacea

14. Sandstone, hard, light-brown; contains many shells of $O$. cretacea.

13. Limestone, sandy, light-brown: contains shells of $O$. cretace $a$ and $O$. ucheensis Stephenson (USGS 17766)

Feet 5

12. Limestone, sandy, hard, fine-grained _......... 1

11. Clay, indurated, light-tan or buff; contains many shells of $O$. cretacea and some of Anomia preolmstedi Stephenson..............................

10. Sand, light-yellow, fine, micaceous, glauconitic(?)

9. Clay (or silt), finely sandy, like bed 10 ; lower part contains large masses of chalklike precipitated calcium carbonate; contains many shells of $O$.

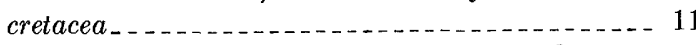

8. Limestone, finely sandy, light-brown, largely composed of shells of $O$. cretacea

7. Sand, light-brown, clayey; contains many shells of 0 . cretacea . .

6. Clay, blocky, light brownish-gray, with much chalklike precipitated calcium carbonate; some shells of 0 . cretacea

5. Bed composed mainly of $O$. cretacea shells and a few shells of Anomia sp., with a matrix of lightbrown, very fine sandy clay ........... 4

4. Chalk, light-buff and white, in silt or clay ....... 3

3. Boulders of hard crystalline limestone filled with shells of $O$. cretacea; Anomia preolmstedi present; softer beds incompletely exposed in ditch but relationship to limestone not clear; many oyster shells appear waterworn (USGS 17776) _..... 12

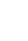

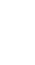

4

3

2


Section along the old Marvyn road $25 / 8$ miles (airline) north by west of Uchee, near center of sec. 7, T. 16 N., R. 27 E., on northeastward-facing slope of a headwater branch of a small tributary of Uchee Creek, Russell County, Ala.-Continued

Eutaw formation-Continued

2. Sand, clayey, light-brown, soft, and white chalk, containing many shells of $O$. cretacea, alternating with light-brown chalky clay, merging downward into bed below

1. Clay, finely sandy, blocky, light-brown and white chalk; contains shells of $O$. cretacea and prints of pelecypods; this bed is slightly more sandy in lower 15 feet........... 36

Concealed to water level of creek . . . . _......... 14

182

In the preceding section layers 17-19 compose a sandy facies probably representing part of the clay unit of the Eutaw formation exposed at Slick Bluff on Chattahoochee River. Ostrea cretacea Morton is recorded as ranging through a thickness of 130 feet of the section (layers 1-16). The new oyster, O. ucheensis Stephenson, is listed in layer 13, where it is associated with $O$. cretacea; this is 20 feet below the top of the Eutaw part of the section. Another lot of fossils from this locality (USGS 17585), recorded as obtained from the upper 20 feet of the $O$. cretacea zone, includes $O$. cretace and $O$. ucheensis. The new species, Pseudoptera securiformis Stephenson (USGS 17211) was obtained near the top of the O. cretacea zone at this locality.

\section{MACON COUNTY, ALA.}

Section north of Creek Stand.-The zone of Ostrea cretacea Morton, which is at least 130 feet thick in northwestern Russell County, continues westward in comparable thickness into Macon County. A section similar, though less complete than the one described by Monroe $2 \frac{5}{8}$ miles north by west of Uchee, is exposed on the Society Hill road 4.1 miles north by west of Creek Stand.

Section on Society Hill road, northward-facing slope of Opintlocco Creek valley about 4.1 miles (airline) north by west of Creek Stand, Macon County, Ala.

Eutaw formation:

7. Sand, massive, greenish-gray, argillaceous, calcareous, partly indurated to calcareous concretionary layers that form projecting ledges on the slope; contains vast numbers of the shells of Ostrea cretacea Morton, more abundant in some layers than in others (USGS 17007); a few shells of Gryphaea wratheri Stephenson present in an indurated layer 10 feet below crest of hill (USGS 18312) _ _ _ 40

6. Sand, soft, light-greenish-gray, calcareous......... 14
Section on Society Hill road, northward-facing slope of Opintlocco Creek valley about 4.1 miles (airline) north by west of Creek Stand, Macon County, Ala.-Continued

Eutaw formation-Continued

Feet

5. Sand, dark-greenish-gray argillaceous, calcareous, glauconitic, partly indurated to nodular calcareous masses in upper 4 or 5 feet

4. Sandstone, concretionary, argillaceous, calcareous_- 1

3. Clay, greenish-gray, calcareous _._._.

2. Sand, partly indurated, greenish-gray, calcareous, with a few shells of $O$. cretacea Morton _. . . . . . _ 1/2

1. Sand, greenish-gray, argillaceous, calcareous _._._. 4 4

73

Neither the base nor the top of the Eutaw formation is exposed in the preceding section. However, the base is probably not more than a few feet below the surface at the crossing of the Society Hill road over Opintlocco Creek. The top of the section is near the crest of the slope overlooking the valley of Opintlocco Creek to the north.

A cut in the Society Hill road 0.85 mile south of the crest of the slope, 3.35 miles north of Creek Stand, exposes 15 feet of greenish-gray argillaceous sand with one indurated layer midway of the section. Oyster shells, apparently a large variety of Ostrea cretacea Morton, are abundant below and above the indurated layer. Assuming a uniform low dip of the Eutaw strata to the south, this oyster-bearing zone is stratigraphically a few feet higher than the topmost stratum of the section 4.1 miles north by west of Creek Stand. The contact of the Eutaw formation with the overlying Blufftown formation should intersect the road somewhere within the next 1 or 2 miles south of the cut.

The stratigraphic range of Ostrea cretacea in eastern Macon County as revealed in the preceding section, is at least 75 feet. The presence of Gryphaea wratheri Stephenson in the upper part of the section is consistent with its known occurrences elsewhere in eastern Alabama.

Section east by north of Hardaway. - The contact between the Eutaw formation and the overlying Blufftown formation is clearly revealed in an outcrop on a country road about 3.5 miles east by north of Hardaway station.

Section in cut on country road, 3.5 miles east by north of Hardaway station in $N W 1 / 4$ sec. $7, \quad T .15 \quad N ., \quad R .23 \quad E .$, Macon County, Ala.

Blufftown formation (lateral merging facies from Mooreville chalk):

Sand, strongly chalky, argillaceous _._. _..........

Conglomerate, including phosphatized molds of mollusks and many large pebbles of phosphatized limestone (as much as 6 inches long) with attached shells of Exogyra, Gryphaea, and Plicatula ........... 1-2 
Section in cut on country road, 3.5 miles east by north of Hardaway station in $N W_{1 / 4}^{1 / 4}$ sec. 7, T. 15 N., R. 23 E., Macon County, Ala.-Continued

Unconformity.

Eutaw formation:

Sand, greenish-gray, fine, micaceous, with many small irregular concretionary masses in the form of nodules; one indurated bed 1 foot thick is 5.5 feet below the contact and another 1 foot thick is 8.5 feet below the contact; the sand contains Ostrea cretacea Morton, Gryphaea wratheri Stephenson, and Exogyra sp_._._._. 11

\section{THE EUTAW FAUNA AND ITS RELATIONSHIPS}

The fauna described in this paper includes most of the present available species in the Eutaw formation of east-central Alabama and an adjacent area in Georgia, that are well preserved or that have a useful significance in determining the stratigraphic position and relationships of the formation. It does not include many poorly preserved or rare fossils that, in our present knowledge, have no such significance. It may be safely assumed that thorough collecting at all available localities in the area would result in the discovery of additional new species and better preserved examples of described species based on incomplete material.

A list of the species, all mollusks, described in this paper is given below. Those marked with an asterisk $\left({ }^{*}\right), 61$ percent of the whole, are identical with, or closely allied to, species in the Snow Hill marl member of the Black Creek formation of North Carolina and South Carolina. It may be assumed from this relationship that many of the species in the Snow Hill faunal assemblage have their progenitors in the fauna of the Eutaw formation. The species in the list marked with a dagger $(\dagger)$ are identical with or closely related to species in the Cusseta sand in the Chattahoochee region, and may be regarded as ancestral to the Cusseta species. The Cusseta sand is interpreted to be approximately synchronous with the Snow Hill marl member.

List of fossils described in this paper

Nucula prepercrassa Stephenson, n. sp.

$\dagger *$ Protarca obliqua Stephenson

Breviarca subinflata Stephenson, n. sp. symmetros Stephenson, n. sp. $\mathrm{sp}$

$\dagger *$ Trigonarca inflata Stephenson, n. sp.

Pseudoptera securiformis Stephenson, n. sp.

Ostrea (Lopha) ucheensis Stephenson, n. sp. cretacea Morton

Gryphaea wratheri Stephenson

Exogyra upatoiensis Stephenson

†*Anomia preolmstedi Stephenson, n. sp.

*Cardium (Trachycardium) ochilleanum Stephenson, n. sp.

$\dagger^{*}$ Legumen aff. L. carolinense (Conrad)

*Cymbophora ochilleana Stephenson, n. sp.

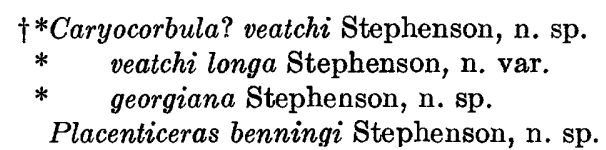

In Alabama, Gryphaea wratheri Stephenson occurs in the upper 35 or 40 feet of the Eutaw formation and also in the basal bed of the Mooreville chalk, where it may be in part indigenous and in part reworked from the Eutaw below. In eastern Alabama a few examples of the species have been found high enough in the lower half of the Mooreville chalk to indicate that they are indigenous there, and not reworked from the Eutaw. The thickness of the beds through which the species ranges has not been accurately determined, but it may not exceed 50 feet.

Gryphaea wratheri is an important index fossil in fixing the stratigraphic position of the Eutaw formation and of the Mooreville chalk and its clay and sand facies, the Blufftown formation. In Texas the species ranges through a zone within the upper half of the Austin chalk that is not known to exceed 35 feet in thickness. (Stephenson, 1936, p. 1-4). The G. wratheri zone is there underlain by the Inoceramus undulatoplicatus zone, which also lies within the upper half of the Austin chalk. Above the G. wratheri zone are three narrowly restricted zones, in succession the zones of Exogyra tigrina, Ostrea centerensis, and O. travisana, the latter at the top of the Austin chalk. It is generally accepted that, in terms of European nomenclature, about the upper half of the Austin is of Santonian age. It follows that, on the indirect evidence afforded by $G$. wratheri, the upper part of the Eutaw formation and the overlying Mooreville and Blufftown formations, are of Santonian age.

\section{SYSTEMATIC DESCRIPTIONS}

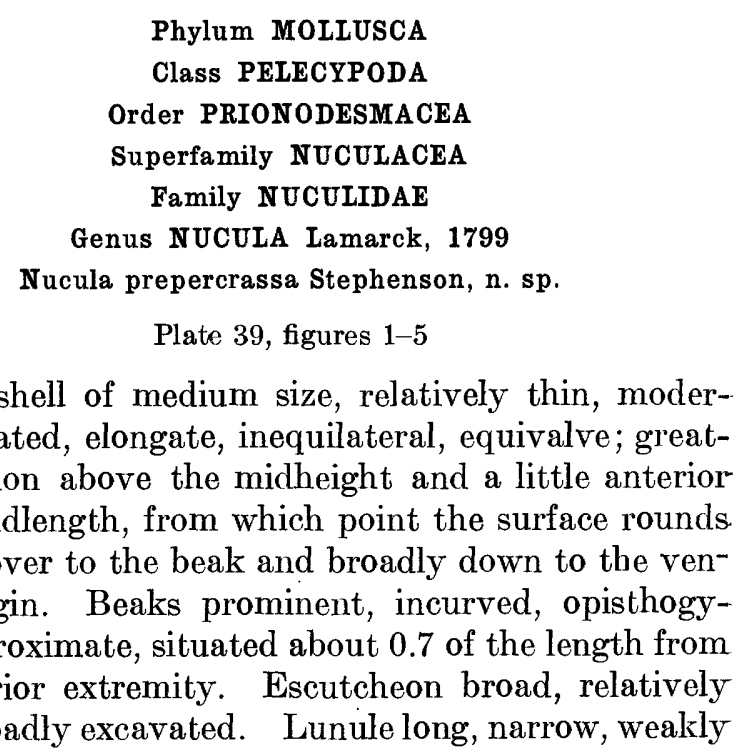


outlined. Anterodorsal margin long, very broadly arched, descending; anterior margin narrowly rounded; ventral margin long, broadly rounded; posterior margin subpointed; posterodorsal margin nearly straight, steeply descending. Surface with fine, weak concentric ridges, and with inconspicuous, low, flat, closely crowded, radiating ribs.

Dimensions of the holotype, a right valve: Length 30 $\mathrm{mm}$, height $20 \mathrm{~mm}$, convexity $8 \mathrm{~mm}$.

Hinge taxodont, teeth numerous, sharp, in two unequal series; in the anterior series the teeth number 30 or more and in the posterior series about 12 . In one paratype, a left valve, a poorly preserved large tooth, oblique forward, is present just back of the deeply impressed resilifer; this tooth fits into a corresponding socket, which is well preserved in the holotype, a right valve. In the holotype, a deeply submerged spoonshaped chondrophore projecting obliquely inward and forward provides a support for the resilium. Adductor scars small, subovate, slightly sunken, high in the shell; pallial line entire. Inner margin finely crenulate.

The few available specimens indicate that this species is similar in form and outline to Nucula percrassa Conrad, from the Owl Creek formation of Mississippi. It differs from Conrad's species in that the shell is much thinner, the hinge is narrower, the chondrophore is larger and projects farther inward, and the adult shells lack the senile inbending of the ventral margins so conspicuously developed in most of the Owl Creek shells; the latter feature in the Owl Creek shells may be a premature senile variation brought about by some inhibiting environmental condition, for some large adult shells in both the Owl Creek and the Ripley formation, that have been referred to Conrad's species, lack the inbending.

Types.-Holotype, from Ochillee Creek near Ochillee, Chattahoochee County, Ga., USGS 15501, USNM 125058; 1 figured paratype, same source, USNM 125059; 3 unfigured paratypes, same source, USNM 12.5060; 1 figured paratype, same source, USGS 5378, USNM 125061.

Distribution and range.-The species is known only from the lower part of the Eutaw formation at the type locality.

\section{Superfamily ARCACEA}

\section{Family ARCIDAE}

Genus PROTARCA Stephenson, 1923

Protarca obliqua Stephenson

Plate 39, figures 9-14

1923. Protarca obliqua Stephenson, N. C. Geol. and Econ. Survey, v. 5, p. 104, pl. 19, figs. 1-3.

1945. Protarca obliqua Stephenson. Nicol, Jour. Paleontology, v. 19 , no. 6, p. 619 .

1950. Protarca obliqua Stephenson. Nicol, Jour. Paleontology, v. 24 , no. 1 , p. 92 , pl. 21 , fig. 10.
1954. Protarca obliqua Stephenson. Nicol, Jour. Paleontology, v. 28 , no. 1 , p. 98 .

The genus Protarca and its type species, P. obliqua, from the Snow Hill marl member of the Black Creek formation, of North Carolina, were described by Stephenson (1923, p. 103-105, pl. 19, figs. 1-3), and descriptions of two smaller specimens from Ochillee Creek at old Ochillee, Chattahoochee County, Ga. were given in the same paper. Two other mediumsized specimens from Ochillee Creek and one juvenile shell from the upper part of the Eutaw formation in western Russell County, Ala., have since been added to the collection. Also the largest known example of the species was recently collected from a calcareous concretion in the Cusseta sand near Peachburg, Bullock County, Ala.; the Cusseta sand is approximately synchronous with the Snow Hill marl member.

Although the Ochillee material is from the lower part of the Exogyra ponderosa zone, and the type from the Snow Hill marl member is from the upper part of that zone, I am unable to recognize any essential differences that would justify a specific separation of the specimens from the two zones. In form, outline and internal features they seem to be identical; although the larger specimen from Ochillee (pl. 39, fig. 9) appears smooth as preserved, the small specimen (pl. 39, fig. 11) shows radial ribs well preserved all over its outer surface such as would probably be present on the young stage of the other shell from Ochillee Creek, were it well preserved in the umbonal region.

The specimen from the Cusseta sand near Peachburg, a left valve (pl. 39, figs. 13, 14), is larger and thicker than the holotype from the Snow Hill marl member of the Black Creek formation in North Carolina. This is the first record of Protarca obliqua in the Cusseta sand.

Types.-Holotype from Snow Hill marl member of Black Creek formation (upper part of Exogyra ponderosa zone), Snow Hill, Greene County, N. C., USGS 5348, USNM 31500; 1 plesiotype from the same zonal position, in the Cusseta sand, cut of Central of Georgia Railroad about 0.7 mile north of Peachburg, Bullock County, Ala., USGS 25478, USNM 125062; 2 plesiotypes from lower part of Eutaw formation (lower part of $E$. ponderosa zone), Ochillee Creek, Chattahoochee County, Ga., USGS 5378, USNM 125063; 1 plesiotype from the same source, USGS 15501, USNM 125064; 1 unfigured example from the same source, USNM 125065.

Distribution.-In addition to the occurrences recorded in the preceding paragraph, one juvenile shell has been found in the upper part of the Eutaw formation in a cut on the HurtsboroMarvyn highway, 5.9 miles south of the Lee County line, Russell County, Ala., USGS 25567, USNM 125066.

Range.-Assuming the correctness of the identifications indicated in this paper the known stratigraphic range of the species is throughout the Exogyra ponderosa zone and the geographic range is from eastern Alabama to eastern North Carolina, in the Atlantic and Gulf Coastal Plain. 


\section{Genus BREVIARCA Conrad, 1872}

Breviarca subinflata Stephenson, n. sp.

Plate 39, figures 6-8

Shell small, thin, of medium inflation, subquadrate in outline, relatively short, subequilateral, equivalved except that the left valve slightly overlaps the right around the margin. Beaks prominent, strongly incurved, nearly direct, slightly separated, situated slightly anterior to the midlength. Umbonal ridge prominent, rounded on the crest, broadly humped and a little sinuous in the linear direction; posterodorsal slope steep; dorsal slopes broadly excavated adjacent to the hinge. Surface rounding down regularly from point of highest inflation to the anterior and ventral margins: surface with fine concentric and faint, fine radial lining.

Dimensions of the holotype, a left valve: Length 13 $\mathrm{mm}$, height $10.3 \mathrm{~mm}$, convexity $4.4 \mathrm{~mm}$.

Cardinal area amphidetic, elongate-subtrigonal; a central amphidetic, triangular ligamental area covering about half the cardinal area is minutely striated at right angles to the length. Hinge broadly arched on its lower margin, truncated above by the straight lower margin of the cardinal area; centrally the hinge is narrow and bears closely spaced, small transverse teeth; the hinge broadens toward the front and toward the rear, the broadened areas bearing numerous successively longer teeth which, away from the center, become more oblique inward and downward, the longer ones becoming angulated in trend. Inner margin smooth; on the interior of the left valve a groove that closely parallels the inner margin marks the contact of the margin of the slightly overlapped right valve. Other internal features not uncovered.

This species is closely allied, possibly ancestral to, Breviarca umbonata (Conrad) from the Snow Hill marl member of the Black Creek formation of North Carolina. (See Stephenson, 1923, p. 114; 1941, p. 86.) Compared with Conrad's species, B. subinflata is not so strongly inflated, is higher with respect to its length, and is more definitely subquadrate, as opposed to subtrigonal, in outline. These differences, though small, together with the lower stratigraphic position of the Georgia species, seem to justify the recognition of the latter as specifically distinct.

Types--Holotype, from Ochillee Creek below bridge at old Ochillee, Chattahoochee County, Ga., USGS 15501, USNM 125067 ; 1 figured paratype, same source, USNM 125068; 2 unfigured paratypes, same source, USNM 125069.

Distribution and range.-Known only from the lower part of the Eutaw formation at the type locality.
Breviarca symmetros Stephenson, n. sp.

Plate 40, figures 1,2

Shell small, moderately inflated, nearly symmetrical in form and in ovate outline, subequilateral, equivalve. Beaks small, subcentral, incurved, direct, slightly separated at the tips. Umbonal ridge practically wanting but the margin bulges slightly in the posteroventral direction. Dorsal margin broadly arched, anterior margin regularly rounded, ventral margin broadly rounded, posterior margin with narrowest curve below, broadening a little above. Surface with low, slightly irregular concentric riblets and fine weak radial lining.

Dimensions of the holotype, a left valve: Length 10.5 $\mathrm{mm}$, height $9.2 \mathrm{~mm}$, convexity $3 \mathrm{~mm}$. One of the paratypes, a left valve is $12 \mathrm{~mm}$ long.

Ligamental area amphidetic, elongate-triangular, scored with transverse, fine, closely spaced grooves; the apex of the area is central below the beak. Hinge plate long, narrow centrally, broadening at each end, arched on its inner margin, set with numerous teeth; the teeth are small and transverse to the hinge line centrally, becoming successively longer and more oblique on the broadened areas in each direction away from the center, attaining horizontality at the ends. Adductor scars large, subequal, subovate, their inner margins bounded by narrow, thin, weak radial carinae. Inner surface smooth, pallial line simple and well away from the inner margin, which is smooth.

Compared with Breviarca subinflata this species is less elongated, less inflated, and lacks an umbonal ridge, in which respect it resembles $B$. perovalis Conrad, $B$. subovalis Conrad, and $B$. congesta Conrad; it is smaller and less elongated than the first two named species, and is a little longer than $B$. congesta; it has a proportionately shorter and smaller ligamental area than either of the three species.

Types.-Holotype, from the upper part of the Eutaw formation in a cut of the new Hurtsboro Marvyn road 5.9 miles south of the Lee County line, in Russell County, Ala., USGS 25567, USNM 125070; 2 unfigured paratypes from the same locality, USNM 125071.

Range.-Known only from the type locality.

\section{Breviarca? sp.}

Plate 40, figure 3

One small incomplete left valve of a bivalve mollusk (USGS 15501), probably a Breviarca, from Ochillee Creek below bridge at old Ochillee, Chattahoochee County, Ga., is similar in form and surface features to $B$. subinflata but is longer in proportion to the height. The umbonal ridge is subangular, sinuous, slightly 
overhanging near the beak, becoming rounded on the crest toward the terminus. Posterodorsal slope narrow and slightly excavated. Beaks strongly incurved, nearly direct, situated about two-fifths of the length from the anterior end. Surface covered with low, weak, concentric ribs asymmetric in cross section, the lower slope of each rib gently inclined toward the venter, the upper slope steep and weakly crenulated by obscure fine radial lining. Dimensions : Length $10.5 \mathrm{~mm}$, height $6.3 \mathrm{~mm}$, convexity about $2.5 \mathrm{~mm}$. USNM 125072 .

\section{Genus TRIGONARCA Conrad, 1862}

Trigonarca inflata Stephenson, n. sp.

Plate 40, figures $4-8$

Shell of medium size, thick-shelled, strongly convex, subtrigonal in outline. Beaks moderately prominent, incurved, opisthogyrate, widely separated, situated a little anterior to the midlength. Umbonal ridge rounded on crest, slightly curved, concave rearward in trend. The main surface rounds over regularly toward the anterior and ventral margins; posterodorsal slope steep, broadly excavated adjacent to margin. Growth lines sharp, resting stages marked by numerous concentric undulations. Obscure radiating lines detectable on parts of surface especially on anterior slope. Dorsal margin arched, anterior margin regularly rounded, ventral margin broadly rounded to nearly straight centrally, posterior margin sharply rounded below, truncated and inclined strongly forward above.

None of the adult shells is completely preserved; the holotype, a left valve, is broken away in a narrow strip around the anterior and ventral margins back to the pallial line. The approximate dimension of the holotype are: Length $60 \mathrm{~mm}$, height $50 \mathrm{~mm}$, convexity $20 \mathrm{~mm}$. None of the available shells exceeds these dimensions.

The ligamental area forms an obtuse-angled subtriangle with longest side at base, shortest side at rear and the third side broadly arched along the anterodorsal margin; six ligamental grooves, chevron-shaped, with short ends of grooves at rear. Hinge taxodont, hinge plate arched on lower margin, truncated on upper margin by the lower straight edge of the ligamental area. Teeth in two series separated by a short edentate area opposite the beak; starting at the rear end of the anterior series, the teeth are small, numerous, closely spaced transverse to hinge line, but in the forward direction they gradually become longer and oblique in trend; on the broad anterior part of the hinge plate of adults the otherwise long, oblique, angulated teeth become broken into small round-topped protuberances of irregular size and distribution. The posterior series of teeth is shorter than the anterior series and from front to rear includes several short slightly oblique teeth, passing into longer angulated teeth and finally into successively shorter and more oblique teeth at the end of the series; all the teeth are striated on the sides at right angles to the hinge plate in the direction of movement. In a young shell (pl. 40, fig. 5) the long teeth are entire, and not broken into irregular protuberences. Anterior adductor scar large, subovate, with a weak, narrow radial ridge along its posterior side; posterior scar smaller, elongated, seated on the outer end of a pronounced radial buttress. Pallial line simple. Inner surface scored with coarse radial grooves in a wide band bordering the inner side of the pallial line.

In form this species is similar to Trigonarca maconensis Conrad but the adult shells are much smaller, apparently more inflated, somewhat smoother, and the ligamental grooves are narrower and more numerous. $T$. inflata probably is ancestral to T. maconensis.

Types.-Holotype, a left valve from upper part of Eutaw formation in cut of Hurtsboro-Marvyn road, 5.9 miles south of Lee County line, in Russell County, Ala., USGS 25567, USNM 125073 ; 1 figured paratype, a small right valve, same source, USNM 125074; 7 more or less incomplete, unfigured paratypes, 6 right valves and 1 left valve, and several fragments, same source, USNM 125075.

Occurrence.-Known only from the type locality as indicated above.

Range.-Upper part of Eutaw formation.

\section{Superfamily PTERIACEA \\ Family PTERIIDAE \\ Genus PSEUDOPTERA Meek, 1873}

Meek (1873, p. $489 ; 1876$, p. 29$)$ proposed the name Pseudoptera as a subgenus of Pteria Scopoli. He designated as genotype Avicula anomala Sowerby, as figured by d'Orbigny (1843-47, p. 478, pl. 392). It would appear that the species illustrated by d'Orbigny must be accepted as the genotype of Pseudoptera, although it is the true $A$. anomala Sowerby, the type of which is not illustrated by Woods (1905, p. 64, pl. 9, fig. 2a). D'Orbigny's figured specimen is from the lower Turonian at Le Mans, Department of Sarthe, France; Sowerby's specimen, the true $A$. anomala is from the Upper Greensand (Albian) at Blackdown, Devonshire, England. The two species probably belong to the same genus.

The specimens referred to Pseudoptera in this paper are similar in form to the one from Le Mans figured by d'Orbigny; the right valves are, however, more flatly compressed. There is also a marked difference in the surface ornamentation, the specimens from the Eutaw formation having radial lining only on the anteroventral slope of left valves. The features of the ligamental area are well shown on two of the specimens from the Eutaw formation, whereas this area was not seen by either Sowerby or d'Orbigny. 


\section{Pseudoptera securiformis Stephenson, n. sp.}

Plate 40, figures 9, 10; plate 41, figures 12-14

Shell large, subtrigonal in outline, inequivalve, strongly inequilateral, bent conspicuously to the left in the adult stage, probably slightly gaping at the rear. In some specimens the curvature to the left is not apparent because of subsequent mechanical flattening. The left valve is moderately convex, the maximum inflation is along the umbonal ridge, which extends in a nearly straight or slightly sinuous course from the umbo to the lower posterior extremity, forming an angle to the hinge line ranging in different individuals from $50^{\circ}$ to $65^{\circ}$. A narrow, sharply upraised, somewhat irregular ridge traverses the crest of the umbonal ridge from the beak to the lower posterior extremity.

The surface back of the umbonal ridge forms a broad very gently convex, slightly undulating slope to the dorsal margin and to the posterior margin; near the hinge line the surface flattens out a little to form an ill-defined posterior wing or rostrum. The anteroventral slope is steep and short and toward the front flares out to form a relatively narrow anterior ear that projects about 10 millimeters in advance of the beak in adults. The right valve is nearly flat or only gently convex, conforming, however, to the curvature of the shell to the left; it is smaller than the left valve, which overlaps it conspicuously along the anteroventral margin.

Dorsal margin of shell straight, about three-fourths the total length of the shell; anterior end subpointed; anteroventral margin descending, long, broadly convex; posterior margin narrowly rounded below; posterodorsal margin broadly convex, inclined forward, curving upward slightly to meet the hinge line. The surface of the shell, especially of the left valve, bears coarse, sharp growth lines. The surface back of the umbonal ridge of the holotype and of some other specimens bears two broad, low diverging radiating folds, but these folds appear to be wanting on many specimens. A series of narrow, obscure to moderately pronounced, irregularly serrated radiating ribs are present on the anteroventral slope of most left valves the shell substance of which is preserved, but this is a variable feature.

Approximate dimensions of the holotype, a left valve: Length $100 \mathrm{~mm}$, height $70 \mathrm{~mm}$, maximum convexity about $25 \mathrm{~mm}$. Some shells attain a length of $120 \mathrm{~mm}$.

The features of the ligamental area are preserved on two of the paratypes. The area is wide and bears 5 or 6 ligamental pits of differing width and spacing; the pits are wider than the intervening spaces. The hinge appears to lack dentition but near the anterior end of the cardinal area a little back of the beak is a narrow, nonprominent ridge extending obliquely inward to the inner edge of the area; in front of and parallel to this ridge is a wide and deep channel that ends beakward in a small pit. No evidence of the position of the main adductor scar can be detected on the available internal molds but there is the clear impression of a small muscle scar (retractor?) 5 or $6 \mathrm{~mm}$ inward from the inner edge of the cardinal area and 25 or $30 \mathrm{~mm}$ inward from the beak.

Types.-Georgia: Holotype, from Ochillee Creek at old Ochillee, Ga., USGS 15501, USNM 125076; 1 unfigured paratype, same source, USGS 5374, USNM 125077; 1 unfigured paratype, same source, USGS 5378, USNM 125078; 1 unfigured paratype, same source, USGS 15501, USNM 125079; 1 figured paratype, same source, USGS 25570, USNM 125082; 1 figured paratype, USGS 5377, USNM 125080. Alabama: 2 figured paratypes, USGS 5384, USNM 125081; two unfigured paratypes, USGS 848, USNM 125083.

Distribution.-Chattahoochee County, Ga.: Chattahoochee River, Broken Arrow Bend, left bank, about 10 miles below Columbus, USGS 847; about 0.5 mile below Broken Arrow Bend, USGS 5385; Upatoi Creek, left bank, 0.25 mile below the old Columbus-Cusseta road bridge, USGS $5373+5377^{1}$; Ochillee Creek near old Ochillee, USGS $5374+5378+15501+25570$; Russell County, Ala.: Chattahoochee River, Broken Arrow Bend, right bank, about 10 miles below Columbus, Ga., USGS $5384+6409$; just below Burdock Landing, USGS 848; Slick Bluff, USGS 845; old Marvyn road, 2.7 miles (airline) north by west of Uchee, USGS 17211; Hurtsboro-Marvyn highway 5.75 miles south of Lee County line, USGS 25575. Perry County, Ala.: Road cut in northward-facing slope 1.7 miles northeast of old Hamburg, USGS 25467.

Range.-The species, as known, ranges through the Eutaw formation of east-central Alabama and adjacent parts of Georgia; one specimen has been found in the basal bed of the Mooreville chalk. Within the Eutaw formation the species ranges from the base nearly to the top.

\section{Superfamily OSTRACEA}

\section{Family OSTREIDAE}

Genus OSTREA Linné, 1758

Subgenus LOPHA Bolten, 1798

Ostrea (Lopha) ucheensis Stephenson, n. sp.

Plate 43, figures 1-5

Shell of medium size, subtrigonal to subcircular in outline, with a tendency for the steeply descending posterodorsal margin to be nearly straight. Right and left valves low-convex to nearly flat. Both valves ornamented with radiating, coarse, round-crested ribs or folds numbering 5 to 10 on different individuals, the folds of one valve corresponding to the intercostal spaces of the other valve, the two valves intermeshing around the margins. A smooth flattish area extending 15 to 30 millimeters out from the beak on each valve of most individuals is unaffected by the folds. Growth lines fine on the umbonal area, becoming coarser to

\footnotetext{
${ }_{1}^{1}$ Numbers connected by the plus sign $(+)$ pertain to the same locality.
} 
roughly imbricating toward the outer margins. Beaks nonprominent, more or less pointed with a tendency to an angulation of $90^{\circ}$ to $115^{\circ}$.

Dimensions of the holotype, a left valve: Length $65 \mathrm{~mm}$, height $66 \mathrm{~mm}$, convexity about $10 \mathrm{~mm}$. The largest shell in the collection, a right valve, is $67 \mathrm{~mm}$ long and $75 \mathrm{~mm}$ high.

Ligamental pit relatively small, short, triangular, straight or slightly curved, opening widely to the interior. Inner margin smooth except for the coarse flutings caused by the intermeshing of the external folds. Adductor scar elongate, more than twice as long as wide, curved, bean-shaped, with the convexity toward the outer margin.

Types.-Holotype, from hill $3 \frac{1}{4}$ miles north-northwest of Uchee, Russell County, Ala., beds of Eutaw formation exposed in gullies in field southwest of road, USGS 17583, USNM 125031; 7 unfigured paratypes, same source, USNM 125032; 3 figured paratypes, USGS 18317, USNM 125033; 5 unfigured paratypes from the preceding locality, USNM 125034; 6 unfigured paratypes, USGS 17585, USNM 125035.

Distribution.-Russell County, Ala.: This species is found 3.2 to 3.4 miles (airline) northwest of Uchee, USGS $17583+18317$; 2.6 to 2.9 miles north by west (airline) of Uchee, USGS $17585+$ $17766+18309 ; 5$ miles northwest (airline) of Seale, USGS 18308; Chattahoochee River at Burdock Landing, USGS 848, and Slick Bluff, USGS $845+5387$. Dallas County, Ala.: One and one-half miles southeast of Summerfield, USGS 19546.

Range.-In Russell County, Ala., the known occurrences of this species are all in the upper part of the Eutaw formation, probably within the upper 50 feet. The one recorded occurrence in Dallas County, Ala., is in the Eutaw formation, but its exact stratigraphic position within that unit has not been determined.

\section{Ostrea cretacea Morton}

Plate 40, figures 11, 12; plate 42, figures 1-17

1834. Ostrea cretacea Morton, Synopsis of the organic remains of the Cretaceous group of the United States, p. 52, pl. 19, fig. 3. (See synonymy in N. C. Geol. and Econ. Survey, v. 5, pt. 1, p. 134, 1923.)

The probable validity of the name Ostrea cretacea Morton for the abundant small oyster shells in the Eutaw formation (Tombigbee sand member) at Erie Bluff, Hale County, Ala., is discussed by Stephenson (1923, p. 135). Further consideration of the subject has afforded no basis for changing the opinion expressed at that time. I believe that the types in the Academy of Natural Sciences, Philadelphia, Pa., came from the Eutaw formation at Erie Bluff, Warrior River, Hale County, Ala., and that the label attributing them to Charleston, S. C., is in error; these specimens agree closely with shells from Erie Bluff.

A comparison of Morton's original figure of Ostrea cretacea with the original figure of $O$. alabamiensis Lea (1833, p. 91, pl. 3, fig. 17) fails to justify Dall's (1898, p. 679) placing of Morton's species in the synonomy of Lea's species; the two species differ markedly in form and outline, and $O$. cretacea is smooth on the inner margin, with the exception of a few obscure crenulations near the hinge of some shells.

Ostrea cretacea Morton is a small simple nearly straight, or only slightly curved, oyster, subovate to subtrigonal in outline, both valves low-convex. Concentric markings pronounced but variable in strength and spacing on different individuals. Radial markings practically absent, but a few obscure radial lines may be detected on some shells, including the holotype. The shells exhibit marked individual variation in outline and convexity; the dorsal margin may be broad or narrow and pointed. Radial color markings of brownish tint are preserved on a rare specimen (pl. 40, fig. 12).

The recorded dimensions of the holotype are: Length $24 \mathrm{~mm}$, height $34 \mathrm{~mm}$, convexity $6 \mathrm{~mm}$. Among the specimens referred to the species in the present paper the largest measured shell, a left valve (pl. 42, fig. 14), is $43 \mathrm{~mm}$ long, $57 \mathrm{~mm}$ high, and has a convexity of about $15 \mathrm{~mm}$.

In Alabama Ostrea cretacea Morton is restricted in vertical range to the Eutaw formation. At Erie Bluff on Warrior River, Hale County, the type locality, the zone containing this species is about 21 feet thick; the zone is uncomformably overlain by the Mooreville chalk of the Selma group. The same zone bearing great numbers of the shells of 0 . cretacea is well exposed at Choctaw Bluff, Greene County, about 6 miles (airline) upstream from Erie Bluff, and at Wolfs Bluff, Hale County, less than a mile downstream from Erie Bluff. In a road cut 1.7 miles northeast of old Hamburg, Perry County, Ala., the zone yielding the species is only about 10 feet thick and occupies the same stratigraphic position below the Mooreville chalk that it does at Erie Bluff.

In east-central Alabama in Macon and Russell Counties the zone of Ostrea cretacea is much thicker than it is in the central and western parts of the state, attaining a measured thickness of 130 feet. In these counties the shells of the species are present in vast numbers in certain layers, especially in the upper part of the zone. In this area the shells average a little larger than at the type locality at Erie Bluff. However, the size ranges from that of the smaller more typical shells to about one and four-fifths that of the holotype, and there seems no reason to question the reference of all the shells to $O$. cretacea Morton. Presumably the average greater size of the shells in some assemblages reflects the more favorable environmental conditions in which the organisms lived.

Types.-Holotype and three paratypes in the collection of the Academy of Natural Sciences of Philadelphia; these are labeled "Charleston, S. C.," but for reasons previously stated this label is believed to be in error, the true type locality being, Erie Bluff, 
Warrior River, Ala. On the assumption that Erie Bluff is the type locality, the four shells illustrated by Stephenson (1923, pl. 28, figs. 11-13, USNM 31541-31544) are topotypes.

Two plesiotypes (essentially topotypes), Choctaw Bluff, Warrior River, Greene County, Ala., USGS 6425, USNM 125025 ; 2 figured topotypes, Erie Bluff, Warrior River, Hale County, Ala., USGS 6428, USNM 125026; 3 pleisotypes, 4.1 miles north of Creek Stand, Macon Co., Ala., USGS 17007, USNM 125027; 7 plesiotypes about 3.1 miles north of Creek Stand, Macon County, Ala., USGS 17006, USNM 125028; 1 plesiotype, 5 miles northwest of Seale, Russell County, Ala., USGS 18308, USNM 125029; 2 plesiotypes, left valves, half mile below Broken Arrow Bend, about 10 miles below Columbus, in Chattahoochee County, Ga., USGS 5385, USNM 125030.

Distribution.-The shells of Ostrea cretacea Morton may be seen in outcrops of the Tombigbee sand member of the Eutaw formation at many places between Greene County, Ala., and Chattahoochee River, and at a few places in Chattahoochee County, Ga. Only a few localities at which the shells have been collected will be recorded here.

Alabama: Greene County, Choctaw Bluff, Warrior River, USGS 6425; Hale County, Warrior River at Erie Bluff, USGS $6428+6932$ and at Wolfs Bluff, USGS 6429; Perry County, 1.7 miles northeast of old Hamburg, USGS 6441; Macon County, 2 miles north of Warrior Stand, USGS 17574, 2.3 miles northwest of Warrior Stand, USGS 17550, 3.1 miles north of Creek Stand, USGS 17006, and 4 miles (airline) north of Creek Stand, USGS 17007; Russell County, 2.5 miles north-northwest of Uchee, USGS $17766+17776$, Hurtsboro-Marvyn road 5.85 miles south of Lee County line, USGS 25575, 3.4 miles northwest of Uchee, USGS 17775 , 5 miles northwest of Seale, USGS 18308 , Chattahoochee River, right bank, at Broken Arrow Bend, USGS 5384, and just below Burdock Landing, USGS 5386.

Georgia: Chattahoochee River, left bank, one-half mile below Broken Arrow Bend, USGS 5385, Upatoi Creek 7 miles southeast of Columbus, USGS $5373+5377+17612$, Ochillee, USGS $5374+5378+15501$.

South Carolina: Well of Charleston Consolidated Railway and Lighting Co., Charleston, at several depths between 1,725 and 2,007 feet.

North Carolina: Well of Clarendon Waterworks Co., Wilmington, at depths between 720 and 1,105 feet; well at Fort Caswell at depth of 1,365 to 1,380 feet. (See Stephenson, 1923, p. 136.)

Range.-Shells of this species occur in vast numbers in certain beds of the Eutaw formation in Alabama and in adjacent parts of Georgia. Some shells that seem indistinguishable from the species have been recorded from overlying formations in Georgia, North Carolina, and South Carolina as high as the upper part of the Exogyra ponderosa zone.

Genus GRYPHAEA Lamarck, 1801, sensu lato

Gryphaea wratheri Stephenson

Plate 41, figures $3-8$

1936. Gryphaea wratheri Stephenson, U. S. Geol. Survey Prof. Paper 186-A, p. 2, pl. 1, figs. 1-4.

The original description of Gryphaea wratheri Stephenson and a record of the distribution of the species as known at that time, are given in the paper cited in the synonymy. (See also Stephenson, 1937, p. 133146.) The species is closely related to $G$. aucella Roemer but averages larger, thicker shelled, broader, less convex and is less strongly incurved at the beak. A consistent difference between the two species that was not mentioned in the original description pertains to a calluslike ridge or fold marking the contact between the two valves on the inner surface of the shell; in a typical example of $G$. wratheri this feature appears as a conspicuous round-crested concentric ridge extending around the inner surface at the line of contact of the two valves, terminating at its two ends below the beak at the inner angles of the ligamental pit. The strength of this ridge varies markedly on different individuals. In $G$. aucella either no ridge is present at this line of contact, or if present is only weakly developed at the ends of the line nearest the ligamental pit. As in most species in the oyster family the shells of $G$. wratheri have marked individual variation in shell characters.

The left valve shown in plate 41 , figure 5 , measures: Length $32 \mathrm{~mm}$, height about $33 \mathrm{~mm}$, convexity about $12 \mathrm{~mm}$. The average size of the Alabama shells is about the same as that of the more typical ones from eastcentral Texas. However, a few may attain a size and thickness considerably greater than the average. One such shell (pl. 41, fig. 3) from House Bluff, Alabama River, Autauga County. measures: Length $56 \mathrm{~mm}$, height $58 \mathrm{~mm}$.

Types.-Holotype, USNM 75506; 2 figured paratypes, USNM 75507, 75507a; 36 unfigured paratypes, USNM 75508; all from a cut on Gaston Avenue just northeast of the intersection of West Shore Drive, 0.7 mile west of the dam of White Rock Reservoir, Dallas, Tex.; all are from USGS coll. 14075. Plesiotype from 0.5 mile north by east of Liberty Hill Church, Macon County, Ala., USGS 19060, USNM 125022; 2 plesiotypes from 0.75 mile north by east of Liberty Hill Church, Macon County, Ala., USGS 17576, USNM 125023. Plesiotype from House Bluff, Alabama River, Autauga County, Ala., USGS 6442-B, USNM 125024.

Distribution in eastern Alabama.-Macon County, upper part of Eutaw formation: 4.25 miles N. of Chesson, USGS 17570; $2 \frac{1}{2}$ miles northeast of Hardaway, USGS $17761 ; 2$ miles north of Edwards, USGS 17572; 7 miles northeast of Hardaway, $3 / 4$ mile(?) north-northeast of Liberty Hill Church, USGS 19060 (1 plesiotype), $17763 ; 0.75$ mile north by east of Liberty Hill Church, USGS 17576 (2 plesiotypes), 17764; about 7 miles northeast of Hardaway, 0.1 to 0.3 mile south of Mount Andrew Church, USGS 17771; Fort Davis road 6 miles south of Tuskegee, USGS $6445 ; 6.1$ miles north by east of Fort Davis, USGS $17569 ; 2.5$ miles north of Cotton Valley crossroad, USGS 17608; 2.35 miles north of Cotton Valley crossroad, USGS 17607; 2.25 miles northnorthwest of Warrior Stand, USGS 18306; 2 miles north of Warrior Stand, USGS 17574; 4.1 miles north by west of Creek Stand, USGS 18312. Macon County, base of Blufftown formation: 0.75 miles north by east of Chesson, USGS 17568; 2.5 miles northeast of Hardaway, USGS 17573.

Russell County, upper part of Eutaw formation: Uchee Creek 200 feet upstream from crossing of U. S. Highway 241 [431], USGS 19079. Russell County, lower part of Mooreville chalk (sandy facies) : 0.55 miles north of Hurtsboro, USGS 18320; 2.5 miles east by north of Hurtsboro, USGS 17604; State Highway 26, 3.4 miles east of Hurtsboro, USGS $18318+25583$. 
Stratigraphic and geologic range.-The original description of the species (Stephenson, 1936, p. 3,4) records it from the upper part of the Tombigbee sand member of the Eutaw formation and from the basal bed of the Mooreville chalk (Selma group) at 15 localities in Alabama between the vicinity of Eutaw, Greene County, and Montgomery, Montgomery County. Part of the shells from the basal Mooreville were mechanically reworked from the underlying Eutaw formation, but some may be indigenous to the basal Mooreville. The more recent field work of W. H. Monroe and others in eastern Alabama has resulted in the discovery of $G$. wratheri in Macon and Russell Counties in the upper part of the Eutaw formation in that area, where also a few indigenous examples of the species have been found in the lower part of the Mooreville chalk (sandy facies).

Subsequent to the publication of the original description, the species has been recorded from the upper part of the Tombigbee sand member of the Eutaw formation in Mississippi (Stephenson and Monroe, 1940, p. 69). The species has been obtained from a core sample (USGS 25369), depth 4;324-4,326 feet, in a well of the Shell Oil Co. in the Chaperall field, Sistrunk-Chapman B1, sec. 13, T. 10 N., R. 7 W., Wayne County, Miss.; this material was submitted by E. H. Rainwater November 22, 1954, and was identified by Norman F. Sohl.

In east central Texas Gryphaea wratheri is present within the upper half of the Austin chalk in a zone having a maximum observed thickness of 35 feet; this zone has been traced through the chalk from the type locality of the species in Dallas, Dallas County, Tex., southward and southwestward to Guadalupe County, Tex.; the species has also been recorded in a marine sand that probably represents the westward continuation of the Blossom sand (late Austin age) at two localities, one about 3 miles north by west of Dodd City, and the other about 5 miles north of Windom (north of Lone Elm Church), Fannin County, Tex.

In recent years the species has been identified in west Texas in Jeff Davis, Reeves, and Presidio Counties. These examples possess the essential features of the species but are notable for their larger average size and their thick shells, indicating vigorous growth in a favorable habitat. Some shells attain lengths as great as $50 \mathrm{~mm}$, heights as great as $64 \mathrm{~mm}$, and a maximum thickness (diameter) of $15 \mathrm{~mm}$.

\section{Genus EXOGYRA Say, 1920}

\section{Exogyra upatoiensis Stephenson}

Plate 43, figures 6-10

1914. Exogyra upatoiensis Stephenson, U. S. Geol. Survey Prof. Paper 81, p. 46, pl. 13, figs. 5-7; pl. 14, figs. 1-3.

1923. Exogyra upatoiensis Stephenson. Stephenson, N. C. Geol. and Econ. Survey, v. 5, p. 164, pl. 45, figs. 1-5.

Two of the three cotypes of this species came from the basal beds of the Eutaw formation at Broken Arrow Bend on Chattahoochee River, about 10 miles below Columbus and the third from a locality on Upatoi Creek 6 miles east-northeast of Broken Arrow Bend, Chattahoochee County, Ga. (7 miles southeast of Columbus). The species is described and illustrated in the two papers cited in the synonymy. The left valves of two of the cotypes are well formed and are ornamented all over with fine, closely spaced, irregular radial costae. The left valve of the larger of the three cotypes shows fine radial costae in the umbonal region around a very large scar of attachment, but elsewhere is partly smooth and partly ornamented with short, irregular costae; the costae on the umbonal ridge are somewhat coarser than on other parts of the surface.

West of Chattahoochee River in Russell and Macon Counties, and on to the west in Alabama, the species is represented in collections from many localities by shells, mainly in the upper part of the Eutaw formation (Tombigbee sand member), that exhibit a wide individual range in the form and ornamentation of their left valves. Among these shells a few possess the features of the originally described shells from the type area, but most of them are irregular in form as a result of crowding or other unfavorable environmental conditions. Many of these nontypical shells have a minor development of fine, closely crowded typical costae in the umbonal region, away from which the surface bears relatively coarse, irregularly distributed costae; on the crests of the costae are scattered spinelike projections formed by the sharp upfolding of concentric lamellae. Although many of these shells are nontypical in appearance there is a reasonable certainty that they all belong to Exogyra upatoiensis Stephenson, and that they are individual variants within the species.

Types.-Cotypes from basal beds of Eutaw formation, Chattahoochee River, Broken Arrow Bend, about 10 miles below Columbus, right bank (Alabama), USGS 5384, USNM 31219, 31221, and Upatoi Creek 7 miles southeast of Columbus, Chattahoochee County, Ga., USGS 5377, USNM 31220. Plesiotypes from upper part of Eutaw formation (Tombigbee sand member) 2.25 miles north-northwest of Warrior Stand, USGS 18306, USNM 125018; and 0.75 mile north by east of Liberty Hill Church, USGS 17576, USNM 125019, Macon County, Ala.; Catoma Creek 5 or 6 miles southwest of Montgomery, Montgomery County, Ala., USGS 17010, USNM 125020. Plesiotype from base of Mooreville chalk, Choctaw Bluff, Warrior River, 4 miles south by east of Eutaw, Greene County, Ala., USGS 25466, USNM 125021.

Distribution.-Greene County, Ala. (base of Mooreville chalk): Choctaw Bluff, Warrior River, USGS 25466 (1 plesiotype). Autauga County, Ala. (upper part of Eutaw formation): House Bluff, Alabama River, USGS 17011. Montgomery County, Ala. (upper part of Eutaw formation): Catoma Creek, 5 or 6 miles southwest of Montgomery, USGS 17010 (includes 1 plesiotype). Macon County, Ala. (Eutaw formation): 4.25 miles north of Chesson, USGS $17570 ; 2.5$ miles northeast of Hardaway, USGS $17761 ; 2$ miles north of Edwards, USGS 17572; 0.5 mile northnortheast of Liberty Hill Church, USGS 17763; 0.75(?) mile north by east of Liberty Hill Church, USGS 19060; 0.75 mile north by east of Liberty Hill Church, USGS 17576 (includes 1 plesiotype); 0.1 to 0.3 mile south of Mount Andrew Church, USGS $17771 ; 2.5$ miles north of Cotton Valley crossroad, USGS $17608 ; 2.25$ miles north-northwest of Warrior Stand, USGS 18306 (includes 1 plesiotype); 2 miles north of Warrior Stand, USGS $17574 ; 4.1$ miles north by west of Creek Stand, USGS $11646+17007+17212$. Russell County, Ala. (Eutaw formation): 3.8 miles north by west of Uchee, USGS 17585 ; 3.25 miles northnorthwest of Uchee, USGS $17583+17584$; Chattahoochee River, 
Broken Arrow Bend, right bank, about 10 miles below Columbus, USGS 5384; near Fort Mitchell Landing, USGS 575. Chattahoochee County, Ga. (basal beds of Eutaw formation): Chattahoochee River, Broken Arrow Bend, left bank, about 10 miles below Columbus, USGS 847 (includes 2 cotypes), 25573; Upatoi Creek, 7 miles southeast of Columbus, USGS $5373+5377$ (includes 1 cotype).

Range.-The species, as at present satisfactorily identified, is restricted in its stratigraphic range to the Eutaw formation in central and east-central Alabama and in Chattahoochee County, Ga., and is recorded from a well at Charleston, S. C., at a depth of 1,974 to 2,007 feet. Examples found in the basal bed of the Mooreville chalk in Alabama are believed to have been mechanically reworked from the underlying Tombigbee sand member of the Eutaw formation.

\section{Superfamily ANOMIACEA}

Family ANOMIIDAE

Genus ANOMIA Linné, 1758

Anomia preolmstedi Stephenson, n. sp.

Plate 41, figure 9-11

Left valve of medium,sized shell thin, subcircular in outline, flattish to strongly convex in different individuals, approximately equilateral. The beak is not preserved on most of the available shells but, as seen on two young left valves, it is small, nonprominent, and is situated about 1 millimeter away from the margin. The surface of well-preserved shells bears very fine, irregular, more or less obscure, closely spaced riblets and fine, closely spaced, overlapping concentric lamellae. The whole outer surface presents a characteristic soft silvery sheen. Hinge edentulus. Inner surfaces of available left valves not well enough preserved to show the muscle scars. The inner surface of the figured paratype is lined with a thin layer of matrix filling, the outer surface of which bears the imprint of the right valve. This imprint is smooth and undulating; a little below the hinge margin is the outline of the oval opening (foramen) through which passed the byssus that provided the mechanism for the attachment of the animal to a foreign object, as for example, to the surface of an abandoned moluscan shell. No right valves are present in the material studied and the imprint just described is the only observed evidence of its presence. Although the genus Anomia is represented in our collections from ihe Cretaceous sediments of the Atlantic and Gulf Coastal Plain by several species and by many individuals, right valves are rarely seen. This is because they are thin and frail and are easily destroyed; in an exceptional example the right valve is protected by the overlying left valve which has retained its natural position on the object of attachment.

Dimensions of the holotype: Length $33 \mathrm{~mm}$, height $31 \mathrm{~mm}$, convexity $9 \mathrm{~mm}$. A large and exceptionally convex left valve measures: Length $35 \mathrm{~mm}$, height $36 \mathrm{~mm}$, convexity about $15 \mathrm{~mm}$.

Shells of this species from the Eutaw and Blufftown formations in the Chattahoochee area south and southeast of Columbus, Ga., have heretofore been referred to Anomia olmstedi Stephenson (Stephenson, 1923, p. 219), but these shells present certain consistent differences from $A$. olmstedi, and occupy a lower stratigraphic position than that species. In $A$. preolmstedi Stephenson the riblets covering the outer surface of the left valve are finer and weaker than the similar riblets in $A$. olmstedi and the concentric growth lamellae, although similar in appearance, are finer and more closely spaced and are not conspicuously upraised along their free margins.

Types.-Holotype, from Chattahoochee River, Broken Arrow Bend, right side, about 10 miles below Columbus, in Russell County, Ala., USGS 6409, USNM 125014; 1 figured paratype from same source, USNM 125015; 8 unfigured paratypes (from same source), 2 mentioned, USNM 125016; 2 unfigured paratypes, the large one measured, from Ochillee, Chattahoochee County, Ga., USGS 5378, USNM 125017.

Distribution.-Alabama, Russell County: Eutaw formation, Broken Arrow Bend, Chattahoochee River, right side, about 10 miles below Columbus, Ga., USGS $5384+6409$ (holotype and 9 paratypes); just below Burdock Landing, Chattahoochee River about 13.5 miles below Columbus, USGS 5386; northeastward facing slope of small branch of Uchee Creek, $25 \% 8$ miles north by west of Uchee, USGS $17759+17765+17769$; gullies southwest of road $3^{1 / 4}$ miles north-northwest of Uchee, USGS 17584. Blufftown formation, Big Bend, Chattahoochee River, 24.5 miles below Columbus, USGS 5388.

Georgia, Chattahoochee County: Eutaw formation, Ochillee Creek at old Ochillee, USGS 5378 (2 paratypes, 1 measured); Chattahoochee River, Broken Arrow Bend, left bank, about 10 miles below Columbus, Ga., USGS 847. Blufftown formation, just below Banks Landing, Chattahoochee River, 27 miles below Columbus, in Stewart County, USGS 5390.

Range.-The species ranges through the Eutaw formation of the Chattahoochee area and upward into the lower part of the Blufftown formation (Mooreville age).

\section{Order TELEODESMACEA}

Superfamily CARDIACEA

Family CARDIIDAE

Genus CARDIUM Linné, 1758

Subgenus TRACHYCARDIUM Mörch, 1853

Cardium (Trachycardium) ochilleanum Stephenson, n. sp.

$$
\text { Plate 41, figures 1, } 2
$$

Shell of medium thickness, subquadrangular in outline, length and height nearly equal, moderately convex, a little oblique toward the lower rear. Beaks of medium prominence, incurved, closely approximate, slightly prosogyrate, situated centrally. Umbonal ridge of medium prominence, obtusely subangular in cross section. Posterodorsal slope steep, broadly exca- 
vated. Main surface rounding down broadly to the anterior and ventral margins. Dorsal margin short, slightly arched; anterior margin semicircular, rounding into the broadly rounded ventral margin; posterior terminus subangular below the midheight; posterior margin above the terminus truncated, inclined forward. The surface bears about 38 well-developed radiating ribs; these are flattish-topped with the exception of several ribs on the umbonal ridge, which are sharp crested. On about the anterior three-fifths of the surface the ribs bear regularly spaced nodes elongated transversely and, where largest, numbering about 8 in a radial distance of 5 millimeters; toward the beak on each rib the nodes become regularly smaller and weaker and are scarcely observable near the tip of the beak. The nodes are in alinement from rib to rib and the rows of nodes appear to be in alinement with the fine growth lines. On the posterior twofifths of the surface the crests of the ribs are essentially smooth with the exception of obscure irregular nodes on the posterodorsal slope.

Dimensions of the holotype, a right valve: Length $28 \mathrm{~mm}$, height $29 \mathrm{~mm}$, convexity about $12 \mathrm{~mm}$. The figured paratype, a left valve, is $24 \mathrm{~mm}$ long and 24 mm high.

The hinge is imperfectly preserved in the holotype and the figured paratype, but the features are observable in part. Hinge narrow; ligamental groove short, opisthodetic; the cardinal teeth of the right valve include a small anterior tooth and a relatively large posterior tooth (broken away), separated by a deep socket; in the left valve the anterior cardinal (also broken away) is large and the posterior one small, the two separated by a deep socket; the lateral teeth are small and well removed from the cardinals. Internal features not uncovered.

This species is closely related to Cardium (Trachycardium) carolinense Conrad (1875), in Kerr, W. C., app. $A$, p. 7; Stephenson, 1923, p. 286), from the Snow Hill marl member of the Black Creek formation, Snow Hill, N. C. It differs from that species in that the ribs are narrower, the interspaces are wider, and the pattern of the nodes, though similar, is much coarser.

Types.-Holotype, a right valve from Ochillee Creek, below bridge at site of old Ochillee, Chattahoochee County, Ga., USGS 15501, USNM 125010; 1 figured paratype, same source, USNM 125012; 2 unfigured juvenile paratypes, a right and a left valve, same source, USNM 125011; 1 unfigured paratype, same source, USGS 25569, USNM 125013.

Distribution and range.-The only available specimens are the types from the Ochillee Creek locality.

\author{
Superfamily VENERACEA \\ Family VENERIDAE \\ Genus LEGUMEN Conrad, 1858 \\ Legumen aff. L. carolinense (Conrad)
}

Plate 44, figures 17-20

The internal and external molds of a species of Legumen Conrad are common in the Eutaw formation in the Chattahoochee River area (Georgia-Alabama). In outline and form, and in the character of the concentric growth markings on the outer surface of the shell this species appears to be essentially like $L$. carolinense (Conrad) from the Snow Hill marl member of the Black Creek formation of North Carolina (Conrad, 1875, p. 8, pl. 2, fig. 10; Stephenson, 1923, p. 321, pl. 81, figs. 5-8). The part of the Chattahoochee River seciion that corresponds in age to the Snow Hill marl member is the Cusseta sand which unconformably overlies the Blufftown formation. Legumen carolinense is recorded from a marine facies of the Cussetta sand exposed at Woolridge Landing, Chattahoochee River, near the northeastern corner of Barbour County, Ala.

In the Chattahoochee region the Eutaw formation forms the lower part of the zone of Exogyra ponderosa, whereas the Cusseta sand forms the upper part of that zone above the Blufftown formation. If the molds and prints of Legumen in the Eutaw are correctly referable to $L$. carolinense the indicated range of the species is through the zone of $E$. ponderosa.

Although the prints and molds of Legumen in the Eutaw formation are like $L$. carolinense in most of their features there are minor differences that appear to be consistent so far as the available material permits one to judge. The pallial sinus, as obscurely preserved on several of the internal molds from the Eutaw, is narrower than it is in L. carolinense, and the anterior margin of the shell appears to be more narrowly rounded. If these differences should prove to be constant features. they might justify a specific separation. However, granting the reality of these differences the conclusion may reasonably be drawn that the form of Legumen so abundantly present in the Eutaw formation is ancestral to L. carolinense in the Cusseta sand and in the Snow Hill marl member of the Black Creek formation. The hinge features, which are so perfectly preserved in the cotypes of $L$. carolinense from North Carolina, are not observable on the molds and prints from the Eutaw formation in the Chattahoochee River area. However, imprints of the inner edges of the cardinal teeth on the 
dorsal margin of the internal molds agree in their arrangement with the cardinal teeth of $L$. carolinense, and the reference of the molds to the genus $L$. Conrad seems well established.

The internal mold shown in plate 44 , figure 19 , measures: Length $58 \mathrm{~mm}$, height $34 \mathrm{~mm}$, thickness 13 $\mathrm{mm}$; the mold shown in plate 44 , figure 17 , measures: Length $52 \mathrm{~mm}$, height $32 \mathrm{~mm}$, thickness $13.5 \mathrm{~mm}$.

Figured specimens.-Broken Arrow Bend, Chattahoochee River, Chattahoochee County, Ga., USGS 6408, USNM 125006; Upatoi Creek, 7 miles southeast of Columbus, in Chattahoochee County, Ga., USGS 5377, USNM 125007; just below Burdock Landing, Chattahoochee River, Russell County, Ala., USGS 848, USNM 125008; 1 unfigured specimen from the same source, USGS 25570, USNM 125009.

Distribution.-Russell County, Ala., Chattahoochee River: Broken Arrow Bend, right bank about 10 miles below Columbus, Ga., USGS 5348+6409; just below Burdock Landing, about 13.5 miles below Columbus, USGS 848 (includes 1 figured specimen) +5386; Slick Bluff about 14 miles below Columbus, USGS 845 +5387 .

Chattahoochee County, Ga.: Chattahoochee River, Broken Arrow Bend, left bank, about 10 miles below Columbus, USGS $847+6408$ (figured); Upatoi Creek, 7 miles southeast of Columbus, USGS 5377 (includes 1 figured specimen); Ochillee Creek at old Ochillee, USGS 5378.

\section{Superfamily MACTRACEA}

Family MACTRIDAE

Genus CYMBOPHORA Gabb, 1869

Cymbophora ochilleana Stephenson, n. sp.

Plate 44, figures 1-3

Shell small, subtrigonal in outline, thin, subequilateral, equivalve, moderately inflated. Beaks prominent, incurved, prosogyrate, slightly separated, situated a little in advance of the midlength; umbonal area narrow. Anterodorsal and posterodorsal slopes steep, broadly excavated; umbonal ridge weakly developed, broadly subobtuse; greatest inflation central above the midheight, from which point the main surface rounds down broadly to the ventral margin. Dorsal margin broadly arched, anterior margin narrowly rounded, ventral margin very broadly rounded, posterior margin narrowly rounded a little below the midheight. Main surface contains very fine incremental lines that become a little coarser toward the ventral margin. On more than half of the anterodorsal slope bordering the margin the incrementals become sharp ridges; this ridged area is abruptly separated from the smoother surface on the slope above it. A similar ridged area is present on the posterodorsal slope where, however, it covers less than half of the slope.

Dimensions of the holotype, a right valve: Length $23.5 \mathrm{~mm}$, height $19 \mathrm{~mm}$, convexity $7 \mathrm{~mm}$.

The hinge is not completely preserved in any of the available specimens; it is very thin and the calcareous shell has become crystallized and is easily shattered in the process of removing the matrix covering it. However, enough of the hinge can be seen in the type material to reveal most of its features. In the left valve two cardinal teeth below the beak are fused together at their upper ends and diverge widely below toward the interior; the posterior one is nearly direct and the anterior one oblique; a deep narrow channel separates: the latter from the thin, sharp margin. The ligamental pit is internal back of the cardinal teeth but is poorly preserved. Well-developed elongated, thin laterals, one anterior and the other posterior are present; these are transversely striated on the sides in the direction of movement. The two cardinal teeth in the right valve are also fused above and diverge widely inward; the separating socket is wide enough to receive both the cardinals of the left valve. The laterals of the right valve are claspers receiving the single laterals of the left valve.

This species is similar in form to Cymbophora trigonalis Stephenson (1923, p. 336) from the Snow Hill marl member of the Black Creek formation of North Carolina. It differs in that the main surface lacks concentric ribbing and is marked only by fine incremental lines. The hinge features of the two species. appear to be essentially identical.

Types.- Holotype, from the Eutaw formation, Ochillee Creek, at old Ochillee, Chattahoochee County, Ga., USGS 15501, USNM 125000; 9 unfigured paratypes, same source, USNM 125001; 1 figured paratype, same source, USGS 5374 , USMN 125002 ; 3 unfigured paratypes, same source, USNM 125003; 1 figured paratype, same source, USGS 5378, USNM 125004; 11 unfigured paratypes, same source, USNM 125005.

Distribution.-All the available examples are from Ochillee Creek, at the site of old Ochillee, Chattahoochee County, Ga., as recorded above under "types."

Range.-Known only from the basal beds of the Eutaw formation at the type locality.

\section{Superfamily MYACEA \\ Family CORBULIDAE}

The family Corbulidae is represented in the Eutaw formation of the Chattahoochee region by many relatively large specimens referable to two or more species. One of these species, Caryocorbula? veatchi Stephenson, n. sp., is closely related to Corbula oxynema Conrad (1875, in Kerr, app. A, p. 11), from the Snow Hill marl member of the Black Creek formation of North Carolina, and another, Caryocorbula? georgiana Stephenson, n. sp., is a species possessing a coarse type of concentric sculpture. Another probably undescribed species, represented by poorly preserved specimens, has still coarser concentric ribbing and is larger than the typical $C$. georgiana.

Vokes has shown (1945, p. 7-10) that the genotype 
of Corbula Lamarck (1799), C. sulcata Lamarck, a Recent species from the coast of Senegal, West Africa, posesses hinge characters sufficiently distinctive and characteristic to separate it generically from many of the Tertiary and Cretaceous species that have been referred to Corbulı. I have examined a right and a left valve labeled $C$. sulcata Lamarck, presumably topotypes (USNM Ter. Coll. Moll. 614185), from the Senegal coast, and am in agreement with Vokes' conclusion. The characters on Lamarck's species that indicate this separation are, in the hinge of the left valve, the absence, of a chondrophore, the presence of a large cardinal tooth, the deep submergence of the ligamental pit (resilifer) and the separation of this pit from the adjacent socket by a thin septum and, in the right valve, the presence of a weak, but distinct, short posterior lateral tooth that fits into a shallow lateral socket in the left valve. For the purpose of comparison illustrations of a right and a left valve of the Recent $C$. sulcata Lamarck are given on plate 45 , figures 1-6. The deep ligamental pit and the prominent cardinal tooth in the left valve, the lateral tooth in the right valve, and the corresponding lateral socket in the left valve are clearly shown in these illustrations.

A score or more of generic names have been introduced by Vokes and others for shells of the family Corbulidae, most of which at one time or another have been referred to Corbula. The species here described under the name, Caryocorbula? veatchi, appears to possess most of the essential generic features of Caryocorbula Gardner (1926, p. 46) from the Claiborne group (Eocene) of Alabama, and is referred questionably to that genus.

\section{Genus CARYOCORBULA Gardner, 1926}

1926. Caryocorbula Gardner, Nautilus, v. 40, p. 46.

1928. Caryocorbula Gardner, U. S. Geol. Survey Prof. Paper 142-E, p. 230.

1945. Caryocorbula Gardner. Vokes, Am. Mus. Nat. History Bull., v. 86, art. 1, p. 11.

Gardner designated Corbula alabamiensis Isaac Lea, from the Claiborne group (Eocene) as the type species of Caryocorbula and described the genus as follows:

Shell small or of moderate dimensions; acutely keeled posteriorly; slightly inequivalve; the right valve a little larger and a little higher relatively than the left; both valves concentrically rugose, the sculpture upon the right valve in some species stronger and more regular than upon the left; a microscopically fine radial lineation developed in some of the later species, particularly upon the posterior keel; ligament, dental, muscle and sinal characters similar [?] to those of Corbula s. s.

The Cretaceous species here referred questionably to Caryocorbula appear to be essentially like that genus in hinge, ligamental and internal features, but they are plumper, more trigonal in outline, more pointed posteriorly and average larger.

The whole group of Cretaceous and Tertiary Corbulidae is in need of critical monographic study.

Caryocorbula? veatchi Stephenson, n. sp.

Plate 44, figures 4-9

Shell of medium size, moderately thick, subtrigonal in outline, inflated centrally and anteriorly, compressed and subpointed posteriorly, rostrate on posterodorsal margin, very inequilateral, inequivalve, the right valve slightly larger and overlapping the left around the margins. Beaks moderately prominent, incurved, slightly prosogyrate, closely approximate, situated about 0.55 the length of the shell from the anterior extremity; right and left beaks of nearly equal height. Umbonal ridge weak but traceable as a thin, weak carina from the beak to the posterior extremity; on the right valve the space between this ridge and the dorsal margin is very narrow; on the left valve this space is slightly wider; it is slightly excavated on each valve.

Dimensions of the nearly complete holotype: Length $20 \mathrm{~mm}$, height $14 \mathrm{~mm}$, thickness $11.6 \mathrm{~mm}$. A paratype, a right valve, shown on plate 44 , figure 6 , measures: Length $21 \mathrm{~mm}$, height $15.5 \mathrm{~mm}$, convexity $6.7 \mathrm{~mm}$.

'The hinge of the right valve bears a strong, trigonal, pointed, upturned cardinal tooth, bordered posteriorly by a deep, wide resilial socket. On the left valve the chondrophore, which supports the ligament, is elevated and is separated from the posterior margin of the shell by a weak, narrow ridge; the middle of the chondrophore is slightly excavated. In front of the chondrophore is a deep trigonal socket for the reception of the cardinal tooth of the right valve. The adductor scars are slightly upraised; the posterior scar is bordered on the front side by a low, narrow ridge that, extended downward, coincides with the very shallow pallial sinus. On the inner surface of the right valve a narrow groove closely paralleling the margin marks the contact of the margin of the overlapped left valve. The surface is ornamented with fine, subdued, somewhat irregular growth ridges that are a little coarser toward the outer margins. Senility is indicated by the abrupt inbending of the outer surface within 1 to 4 millimeters of the ventral and anterior margins of adult shells.

Compared with the closely related Caryocorbula? oxynema (Conrad), from the Snow Hill marl member of the Black Creek formation of North Carolina, this species possesses a thicker shell, a heavier hinge, and a finer and weaker pattern of concentric growth ridges.

Types.-Holotype, from Ochillee Creek at old Ochillee, 
Chattahoochee County, Ga., USGS 5374, USNM 125036; 2 unfigured paratypes, same source, USNM 125037; 2 figured paratypes, same source, USGS 15501, USNM 125038; 14. unfigured paratypes, same source, USNM 125039; and 3 unfigured paratypes, same source, USGS 5378, USNM 125040.

Named in honor of Otto Veatch, the original collector, and one time assistant State Geologist of Georgia.

Distribution.-Alabama, Russell County: Broken Arrow Bend, Chattahoochee River, right bank, USGS 5384.

Georgia, Chattahoochee County: Broken Arrow Bend, Chattahoochee River, left bank, USGS 847; Ochillee Creek near old Ochillee (type locality), USGS $5374+5378+15501+25569$.

Range.-Lower part of Eutaw formation, Chattahoochee area, Georgia-Alabama. Closely related large shells belonging to two or more species of Caryocorbula? are present at a higher stratigraphic position in the Cusseta sand (Alabama-Georgia) and in the Snow Hill marl member of the Black Creek formation of North Carolina.

\section{Caryocorbula? veatchi longa Stephenson, n. var.}

Plate 44, figures 10-13

This shell from the upper part of the Eutaw formation resembles Caryocorbula? veatchi but it averages a little larger, is proportinately longer, and is not quite so strongly inflated; its concentric surface sculpture, though weak and moderately fine, is nevertheless stronger than that of $C$. ? veatchi; the features of the chondrophore in the left valve are more strongly marked.

Dimensions of the holotype, a right valve: Length $23 \mathrm{~mm}$, height $15 \mathrm{~mm}$, convexity $6.5 \mathrm{~mm}$.

Types.-Holotype, a right valve, from Hurtsboro-Marvyn road 5.9 miles south of Lee County line in Russell County, Ala., USGS 25567, USNM 125041; 1 figured paratype, same source, USNM 125042; 8 unfigured paratypes, same source,- USNM 125043.

Distribution.-In addition to the type locality (USGS 25567) poorly preserved specimens of the species have been identified from two localities on the Chattahoochee River in Russell County: just below old Burdock Landing, USGS 848, and at Slick Bluff, USGS $845+5387$. Shells of comparable size but still more elongated, and having still stronger concentric sculpture occur at higher stratigraphic positions in the Blufftown formation and in the Cusseta sand.

Range.-As here restricted this variety is known only from the upper part of the Eutaw formation in Russell County, Ala.

Caryocorbula? georgiana Stephenson, n. sp.

Plate 44, figures 14-16

Shell of medium size, subtrigonal in outline, strongly inflated centrally and anteriorly, humped in the anteroumbonal region, compressed and narrow posteriorly, inequilateral, inequivalve, the right valve slightly larger than the left. Beaks prominent, strongly incurved, prosogyrate at the tips, closely approximate, situated about centrally. Umbonal ridge of the right valve narrow, sharply defined, sinuous, paralleled on the marginal side by a narrow radial excavation and on the other side by a broad radial excavation. Anterodorsal slope of right valve steep, overhanging near the beak; posterodorsal slope also overhanging a little near the beak. Anterodorsal margin broadly arched, anterior margin evenly rounded, narrower than a semicircle, ventral margin broadly rounded, posterior margin with a short truncation below midheight, posterodorsal margin straight, strongly inclined forward.

The main surface of the right valve bears concentric ridges that are small and fine in the umbonal area and increase in strength and coarseness outwardly, becoming very coarse adjacent to the ventral margin; these ridges are round crested and bear fine growth lines on the sides and in the interspaces; the ridges become smaller and much finer on the dorsal slopes. The surface of the left valve is not preserved on the available material, but imprints of small areas indicate that this valve lacks coarse ribbing and bears only small incremental ridges.

Dimensions of the holotype, a right valve: Length 17 $\mathrm{mm}$, height $13 \mathrm{~mm}$, convexity about $6 \mathrm{~mm}$. Individuals may attain a length of $20 \mathrm{~mm}$.

The hinge of the right valve includes one prominent, upcurved, trigonal cardinal tooth back of which is a deep, broad resilial depression; in front of the cardinal tooth is an oblique channel opening inward. Lateral teeth are wanting. A rubber impression made from the internal mold of a left valve (pl. 44, fig. 16) shows that the internal ligament is seated on a raised chondrophore directed obliquely to the rear and inward; in front of the chondrophore is a deep, wide socket for the reception of the cardinal tooth of the right valve. The adductor scars occupy raised platforms the impressions of which are conspicuous on internal molds; the posterior platform is a little higher than the anterior one. The pallial sinus is very shallow.

In the clay facies of the Eutaw formation exposed on Chattahoochee River at old Burdock Landing and at Slick Bluff, Russell County, Ala., are many internal and external molds of Caryocorbula? that have the form and outline of C.? georgiana, but average larger and show a wider range in individual variation in the coarseness of their concentric sculpture. Most of them are flattened and distorted by mechanical pressure. They are referred questionably to $C$. ? georgiana.

Types.-Holotype, from Ochillee Creek south of bridge at old Ochillee, Chattahoochee County, Ga., USGS 15501, USNM 125044; 1 figured paratype, same source, USNM 125045; 1 figured paratype, same source, USGS 5378, USNM 125046; 28 unfigured paratypes, same source, USNM 125047; 12 questionable examples from just below old Burdock's Landing, Chattahoochee River, Russell County, Ala., USGS 848, USNM 125048.

Distribution.-Ochillee Creek near old Ochillee, Chattahoochee 
County, Ga., USGS 5378+15501; Broken Arrow Bend, Chattahoochee River, left bank, USGS 847; questionably on Chattahoochee River, right bank just below old Burdock Landing, USGS 848; questionably on Chattahoochee River, right bank at Slick Bluff, USGS $845+5387$.

Range.-The types and duplicate specimens are from the lower part of the Eutaw formation in the Chattahoochee River area, Georgia-Alabama; questionably identified specimens are present in the upper part of the formation.

\section{Class CEPHALOPODA}

Order AMMONOIDEA

\section{Family PLACENTICERATIDAE}

\section{Genus PLACENTICERAs Meek, 1870}

Placenticeras benningi Stephenson, $n$. sp.

Plate 44, figures 21, 22; plate 45, figures 7-11

The species, as seen in the holotype and 15 paratypes, attains medium size for the genus; all the paratypes are smaller than the holotype. Shell strongly involute, compressed on the flanks, with greatest inflation of the volution at the umbilical shoulder, the flanks converging outward toward the venter. In early stages the flanks are nearly flat but as growth proceeds they become broadly convex in profile. The flattened venter is narrow for the genus. In young stages retaining the shell the venter is slightly excavated and is bordered on each ventral angle by a very thin upraised rim. At a radius of 35 to $50 \mathrm{~mm}$ the venter begins to become rounded. In some of the smaller stages this rounding is accompanied by a smoothing out of the surface, apparently indicating maturity at an earlier stage than that attained by the holotype. Beginning at a radius of about $55 \mathrm{~mm}$ on the holotype a row of small obscure elongated nodes 8 to $10 \mathrm{~mm}$ apart on each ventral angle can be detected; this part of the venter is considerably waterworn. These nodes are wanting on the younger paratypes whose venters become rounded at early stages.

The umbilicus is small with steeply sloping sides; the umbilical shoulder is at first obtusely subangular but becomes rounded in adults. In early stages a succeeding whorl envelops three-fourths or more of the preceding whorl, but in later stages only about two-thirds of the preceding whorl is enveloped. In young shells the flanks of the whorls are nearly smooth but they exhibit a row of gentle radially elongated undulations about two-fifths the width of the flank inward from the ventral angle; these increase in strength forward and they increase in spacing from $5 \mathrm{~mm}$ apart on early stages to $20 \mathrm{~mm}$ or more apart on adults; they do not develop into nodes proper. At a diameter of $65 \mathrm{~mm}$ or less weak nodes begin to appear on the umbilical shoulder; at first these are spaced 12 to $15 \mathrm{~mm}$ apart but in the forward direction the spacing increases to 20 to $24 \mathrm{~mm}$ on adults, and the nodes increase in size to moderate prominence.

The sutures are best seen on several of the young paratypes; the description is based on the one shown in plate 44, figure 21. The ventral lobe is broad and shallow with a pair of short digitate diverging prongs, one on either side; these prongs inclose a broad, short ventral saddle which is divided by a relatively broad very shallow lobule. The first lateral saddle is relatively very broad and short and is subdivided by four short bifid subsaddles, separated by three small sublobes; the subsaddles and sublobes are further indented with tiny lobules. The first lateral lobe is narrow and trifid, the sublobes are indented with lobules. The second lateral saddle is less than half as broad as the first, is bifid with sublobes, and is further indented with lobules. From the venter to the line of involution there are 11 saddles separated by 10 lobes, both saddles and lobes becoming simpler inward; the last saddle at the line of involution is quite small and plain. The third lateral lobe inward from the venter is larger than any of the others. The inner part of the suture beyond the line of involution is not uncovered.

The holotype, chosen for its size (pl. 45, fig. 7), has suffered considerable mechanical compression and some distortion, especially the part representing the living chamber. The measurements that can be given are therefore only approximate and include the following: Maximum diameter $170 \mathrm{~mm}$, maximum radius center to venter $103 \mathrm{~mm}$; at a diameter of about $120 \mathrm{~mm}$ the transverse diameter of the volution is about $35 \mathrm{~mm}$; at the same diameter the height of the volution from the line of involution to the venter is about $52 \mathrm{~mm}$. A more accurate measurement of the young paratype shown in plate 44, figure 21 , can be made as follows: Greatest diameter $87 \mathrm{~mm}$; maximum radius center to venter $50 \mathrm{~mm}$; height of volution line of involution to venter about $40 \mathrm{~mm}$; transverse diameter between nodes $21 \mathrm{~mm}$; same on nodes $25 \mathrm{~mm}$; maximum diameter of umbilicus measured shoulder to shoulder $30 \mathrm{~mm}$; the same measured line of involution to line of involution $20 \mathrm{~mm}$.

This species is closely related to Placenticeras guadalupe (Roemer) from the Austin chalk (Inoceramus undulatoplicatus zone) at the Falls of the Guadalupe, 2 miles below the highway bridge at New Braunfels, Tex. (Roemer, 1852, p. 32, pl. 2, fig. $1 a, b$.) Compared with the illustrations of Roemer's species this species is more compressed, the nodes on the ventral angles are much weaker or absent, and instead of a row of nodes on the outer flank it possesses a corresponding row of undulations and this row is a little farther removed from the adjacent paralleling ventral angle; the saddles and lobes of the suture also seem to be consistently shorter. The 
specimen referred by Hyatt (his collection) to Roemer's species (Hyatt, 1903, p. 197, pl. 29), as figured, does not appear to be correctly identified. Compared with Roemer's figured specimen it shows no indication of the presence of a row of small relatively closely spaced nodes on each ventral angle and on the adult stage the shoulder nodes become much larger, elongated and directed obliquely forward.

Placenticeras sancarlosense Hyatt (1903, p. 200, pl. 30 ; pl. 31, figs. 1, 2), from San Carlos, Presidio County, Tex., is also nearly related to $P$. benningi, but it is stouter, more closely coiled, possesses a row of nodes instead of undulations on the outer flank, and has well developed alternating nodes on the ventral angles at an early stage (diameter of $40 \mathrm{~mm}$ or less).

Assuming that all the specimens here referred to $P$. benningi are correctly identified there is considerable individual variation of form within the species. Some of the younger shells begin to thicken and round over on the venter, at the same time becoming smoother on the venter and outer flank, than is true of the holotype which represents a much later and larger stage of growth.

Types.-Holotype, from basal beds of Eutaw formation Broken Arrow Bend, Chattahoochee River (Alabama side) USGS 5384, USMN 125049; 1 figured paratype, from the same zone on Upatoi Creek, 7 miles southeast of Columbus, USGS 5377, USNM 125050; 2 figured paratypes from same zone, on Ochillee Creek, old Ochillee (below bridge), Chattahoochee County, Ga., USGS 15501, USN M 125051;2 unfigured paratypes, same source, USNM 125052; 6 unfigured paratypes, same source, USGS 25569, USNM 125053; 4 unfigured paratypes from old Ochillee (upstream from bridge), USGS 25570, USNM 125054.

Named in honor of Brig. Gen. Henry L. Benning, a distinguished Confederate Army officer for whom Fort Benning was named, and whose home was in Columbus, Ga.

Distribution.-The known occurrences of this species in the Chattahoochee region are recorded under the heading "types" above.

Range.-The species is known only from the basal beds of the Eutaw formation in the Chattahoochee region.

\section{REFERENCES}

Berry, E. W., 1923, The age of the supposed Lower Cretaceous of Alabama: Washington Acad. Sci. Jour., v. 13, no. 20, p. 433-435.

Conrad, T. A., 1860, Descriptions of new species of Cretaceous and Eocene fossils of Mississippi and Alabama: Acad. Nat. Sci. Phila. Jour., 2d ser., v. 4, p. 275-298, pls. 46, 47.

- 1875 , Descriptions of new genera and species of fossil shells of North Carolina, in Kerr, W. C., Physical geography, résumé, economical geology, N. C., Geol. Survey Rept., v. 1, app. $A$, p. 1-13, pls. $1,2$.

Dall, W. H., 1898, Contributions to the Tertiary fauna of Florida: Wagner Free Inst. Sci. Trans., v. 3, pts. 1-6, 1654 p., 60 pls.

D'Orbigny, Alcide, 1843-47, Description des animaux invertebrés; Lamellibranches: Paléontologie française, terraine crétacé, 1st ser. v. 3, 807 p. pls. 237-489.
Eargle, D. H., 1950, Geologic map of the Selma group in eastern Alabama: Oil and Gas Investigations, preliminary map 105 (with text).

Gardner, Julia, 1926, The nomenclature of the superspecific groups of Corbula in the lower Miocene of Florida: Nautilus, v. 40 , no. 2 , p. $41-46$.

Hyatt, Alpheus, 1903, Pseudoceratites of the Cretaceous: U. S. Geol. Survey Mon. 44, 351 p., 47 pls.

Langdon, D. W., 1890, Variations in the Cretaceous and Tertiary strata of Alabama: Geol. Soc. America Bull., v. 2, p. 587-606.

Lea, Isaac, 1833, Tertiary formation of Alabama, in Lea, Isaac, 1833, Contributions to geology, Phila., 227 p., p. 29-208, pls. 1-6.

McCallie, S. W., 1903, Sandstone dikes near Columbus, Georgia: Am. Geologist, v. 32, p. 199-202.

Meek, F. B., 1873, Preliminary paleontological report, consisting of lists of fossils with descriptions of some new types: U. S. Geol. Survey Terr. 6th Ann. Rept., p. 429-518.

1876, A report on the invertebrate Cretaceous and Tertiary fossils of the Upper Missouri country: U. S. Geol. Survey Terr., 9th Ann. Rpt., 629 p., 85 figs., 45 pls.

Monroe, W. H., 1941, Notes on deposits of Selma and Ripley age in Alabama: Ala. Geol. Survey Bull. 48, $150 \mathrm{p}$.

1947, Stratigraphy of outcropping Cretaceous beds of southeastern United States: Am. Assoc. Petroleum Geologists Bull., v. 31, no. 10, p. 1817-1824.

Monroe, W. H., Conant, L. C., and Eargle, D. H., 1946, PreSelma Upper Cretaceous stratigraphy of western Alabama: Am. Assoc. Petroleum Geologists Bull., v. 30, no. 2, p. 187-212, 4 figs.

Roemer, Ferdinand, 1852, Die Kreidebildungen von Texas und ihre organischen Einschlüsse, Bonn, bei Adolph Marcus, 100 p., 11 pls.

Stephenson, L. W., 1911 [1912], Cretaceous [of Georgia], in Veatch, Otto, and Stephenson, L. W., Geology of the Coastal Plain of Georgia, Ga. Geol. Survey Bull., no. 26, p. $66-215$.

1914, Cretaceous deposits of the eastern Gulf region: U. S. Geol. Survey Prof. Paper 81, 77 p., 21 pls.

1923, The Cretaceous formations of North Carolina; pt. 1, Invertebrate fossils of the Upper Cretaceous formations: N. C. Geol. and Econ. Survey, v. 5, 592 p., 100 pls. 1936, New Upper Cretaceous Ostreidae from the Gulf region: U. S. Geol. Survey Prof. Paper 186-A, p. 1-12, pls. $1-3$.

1937, Stratigraphic relations of the Austin, Taylor, and equivalent formations in Texas: U. S. Geol. Survey Prof. Paper 186-G, p. 133-146, pl. 44, fig. 7.

1941, The larger invertebrate fossils of the Navarro group of Texas: Tex. Univ. Pub., Bull. 4101, 641 p., 95 pls.

Stephenson, L. W., and Monroe, W. H., 1938, Stratigraphy of Upper Cretaceous series in Mississippi and Alabama: Am. Assoc. Petroleum Geologists Bull., v. 22, no. 12, p. 16391657.

1940, The Upper Cretaceous deposits [Mississippi]: Miss. State Geol. Survey, Bull. 40, 296 p., 15 pls.

Veatch, Otto, 1909, Second report on the clays of Georgia: Ga. Geol. Survey Bull., no. 18, 453 p.

Vokes, H. E., 1945, Superspecific groups of the pelecypod family Corbulidae: Am. Mus. Nat. History Bull., v. 86, art. 1, p. 1-32, pls. 1-4.

Woods, Henry, 1904-12. A monograph of the Cretaceous Lamellibranchia of England: Palaeont. Soc. Mon., v. 2, pts. 1-9, 473 p., 62 pls. 


\section{INDEX}

[Italic numbers indicate descriptions]

A

Acknowledgments
alabamiensis, Corbula
Ostrea
Ammonoidea.
Anchura
anomala, Avicula
Anomia olmstedi $\quad$ preolmstedi
sp
Anomiacea
Arcacea
aucella, Gryphaea
Austin chalk.
Aricula anomala

benningi, Placenticeras

$230,231,232,234,247,248 ;$ pl.44

Black Creek formation

$229,232,233,234,240,242,243,246$

Breviarca congesta

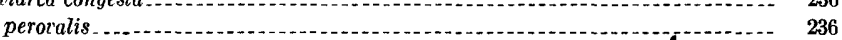

subinflata

suboralis..................... 236

symmetros . . . . . 234

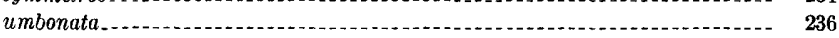

$\mathrm{sp} \ldots \ldots \ldots$

Broken Arrow Bend, fossils from

Burdock Landing, fossils from . .

$\mathrm{C}$

(Camptonectes) Pecten.

Cardiacea.. .6242

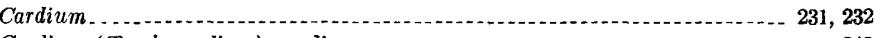

Cardium (Trachycardium) carolinense

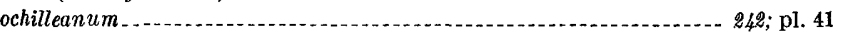
carolinense, Legumen carolinense, Cardium (Trachycardium)

Caryocorbula georgiana..... 230, 234, 244, 246; pl. 44 oxynema

veatchi

245

Caryocorbula veatchi longa............................. 232, 246; pl. 44

centerensis, Ostrea

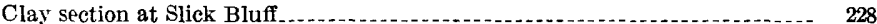

congesta, Breviarca.

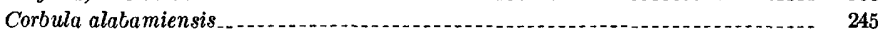

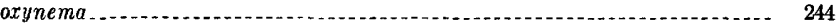

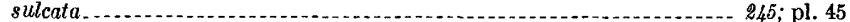

Corbulidae............... 244

Creek Stand, fossils from near. .

cretacea, Ostrea......... 228, 230, 231, 233, 234, 239, 240; pls. 40, 42

Cusseta sand

$234,243,246$

Cymbophora ochilleana. trigonalis.

Cyprimeria.

depressa, Cyprimeria

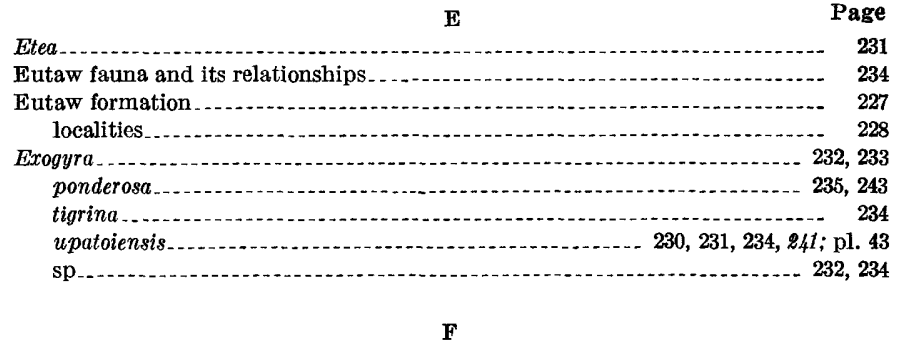

Fort Decatur, fossil plants from.

231

G

Gardner, Julia, quoted.

georgiana, Caryocorbula 230, 234, 244, 246;

Gordo formation of Tuscaloosa group...... 228, 231

Gryphaea

aucella

wratheri ................. 234, 240, 241; pl. 41

I

Idonearca

inflata, Trigonarca..... 234, 237; pl. 40

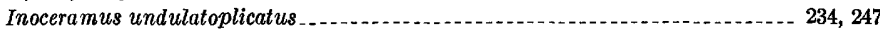

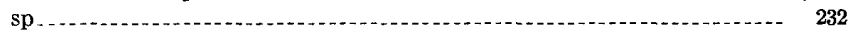

$\mathrm{L}$

Legumen carolinense

Leptosolen........................ 231

Liopistha sp . . .

List of fossils. . . . . . . . .

Location of most important fossil-bearing strata $\ldots \ldots \ldots$

longa, Carycorbula veatchi

(Lopha) ucheensis, Ostrea ......... 230, 238; pl. 43

M

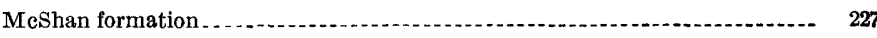

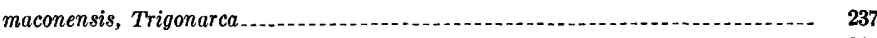

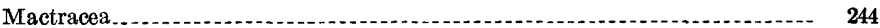

Mooreville chalk

Myacea. .

Nucula prepercrassa $\ldots \ldots \ldots \ldots \ldots \ldots \ldots$

Nuculacea

oblique, Protarcan $231,342,244 ; \mathrm{pl} .44$

ochilleanum, Cardium (Trachycardium) ........................... 242; pl. 41

Ochillee Creek, fossils from

olmstedi, Anomia

Ostracea

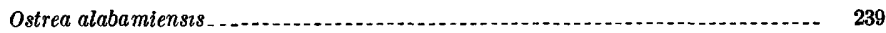

centerensis . .

cretacea ... . ............. 228, 230, 231, 233, 234, 239, 240; pl. 40

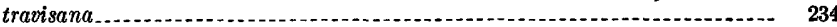

ucheensis............. 230, 232, 233 


\begin{tabular}{|c|c|}
\hline Page & Page \\
\hline Dstrea cretacea zone...... & Slick Bluff, fossils from \\
\hline Qstrea (Lopha) ucheensis ........... & Snow Hill marl member $\ldots$ \\
\hline Owl Creek formation & Stratigraphic section, east by north of Hardaway station \\
\hline ynema, Caryocorbula & Ochillee Creek \\
\hline Corbula & old Marvyn road, northwest of Uchee \\
\hline & Society Hill road, north of Creek Stand \\
\hline $\mathrm{P}$ & (n) \\
\hline Pecten (Camptonectes). & 228 \\
\hline 236 & subinflata, Breviarca...... \\
\hline 231 & subovalis, Breviarca \\
\hline 230, 231, 232, 234, 247, 248: pl. 44 & sulcata, Corbula \\
\hline 247 & symmetros, Berviarca \\
\hline - & \\
\hline 233 & $\mathrm{~T}$ \\
\hline ponderosa, Exogyra & Tellina $\ldots \ldots \ldots$ \\
\hline preolmstedi, Anomia & tigrina, Exogyra $a_{-}$ \\
\hline prepercrassa, Nucula & Tombigbee sand member \\
\hline Protarca obliqua & (Trachycardium) carolinense, Cardium \\
\hline - 237 & ochilleanum, Cardium \\
\hline 230, 231, 233, 234, 238; pl. 40 & 234 \\
\hline 237 & trigonalis, Cymbophora \\
\hline ( & $\begin{array}{l}\text { Trigonarca } \\
\quad \text { inflata }\end{array}$ \\
\hline quadalupe, Placenticeras........... & 237 \\
\hline & 231 \\
\hline $\mathbf{R}$ & Tuscaloosa group \\
\hline 228,248 & \\
\hline Ripley formation & $U$ \\
\hline Dencorlo & $\begin{array}{l}\text { Uchee, fossils from near. } \\
\text { ucheensis, Ostrea. }\end{array}$ \\
\hline sancarlosense, Placenticeras....... & $($ Lopha $) \ldots . . .230,238 ;$ pl. 43 \\
\hline 234 & umbonata, Breviarca.... 236 \\
\hline cription of, Broken Arrow Bend & undulatoplicatus, Inoceramus \\
\hline ling & Upatoi Creek, fossils from \\
\hline f Hardaway station.......... 233 & upatoinensis, Exøgyra. \\
\hline ro-Marvyn road, south of Lee County line & \\
\hline 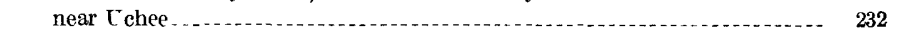 & $\mathrm{V}$ \\
\hline d. & veatchi, Caryocorbula \\
\hline 231 & Carycorbula \\
\hline 229,230 & 243 \\
\hline southwest of Phenix City & Volutomorpha \\
\hline est of Youngs Bridge...... & \\
\hline Uchee Creek valley .... & W \\
\hline Upatoi Creek & wratheri, Gryphaea \\
\hline $\begin{array}{l}\text { Selma group } \\
\text { securiformis, Pseudoptera }\end{array}$ & $\mathbf{Y}$ \\
\hline Serpula & ungs Bridge, fossils from near \\
\hline
\end{tabular}


PLATES 38-45 


\section{PLATE 38}

$A$, The unconformable contact of the Eutaw formation on the Gordo formation (Tuscaloosa group) in a cut of the old ColumbusSeale road (near the present U. S. Highway 431) about 4 miles southwest of Phenix City (opposite Columbus, Ga.) in Russell County, Ala.

$B$, Light-gray silty, micaceous shale of the upper part of the Eutaw formation exposed in Slick Bluff on Chattahoochee River, rigbt bank, about 14 miles below Columbus, Ga.

$C$, Layers of nodular calcareous, fossiliferous concretions in dark-gray sandy marine clay in right bank (Alabama side) at Broken Arrow Bend, Chattahoochee River, about 10 miles by the river below Columbus, Ga.

$D$, Calcareous fossiliferous sandstone in the bed of Ochillee Creek below the mill dam at the site of old Ochillee, about 10 miles southeast of Columbus Ga.; the dam and mill have disappeared and the creek is now crossed at this place by a bridge of one of the roads of the Fort Benning Military Reservation. 

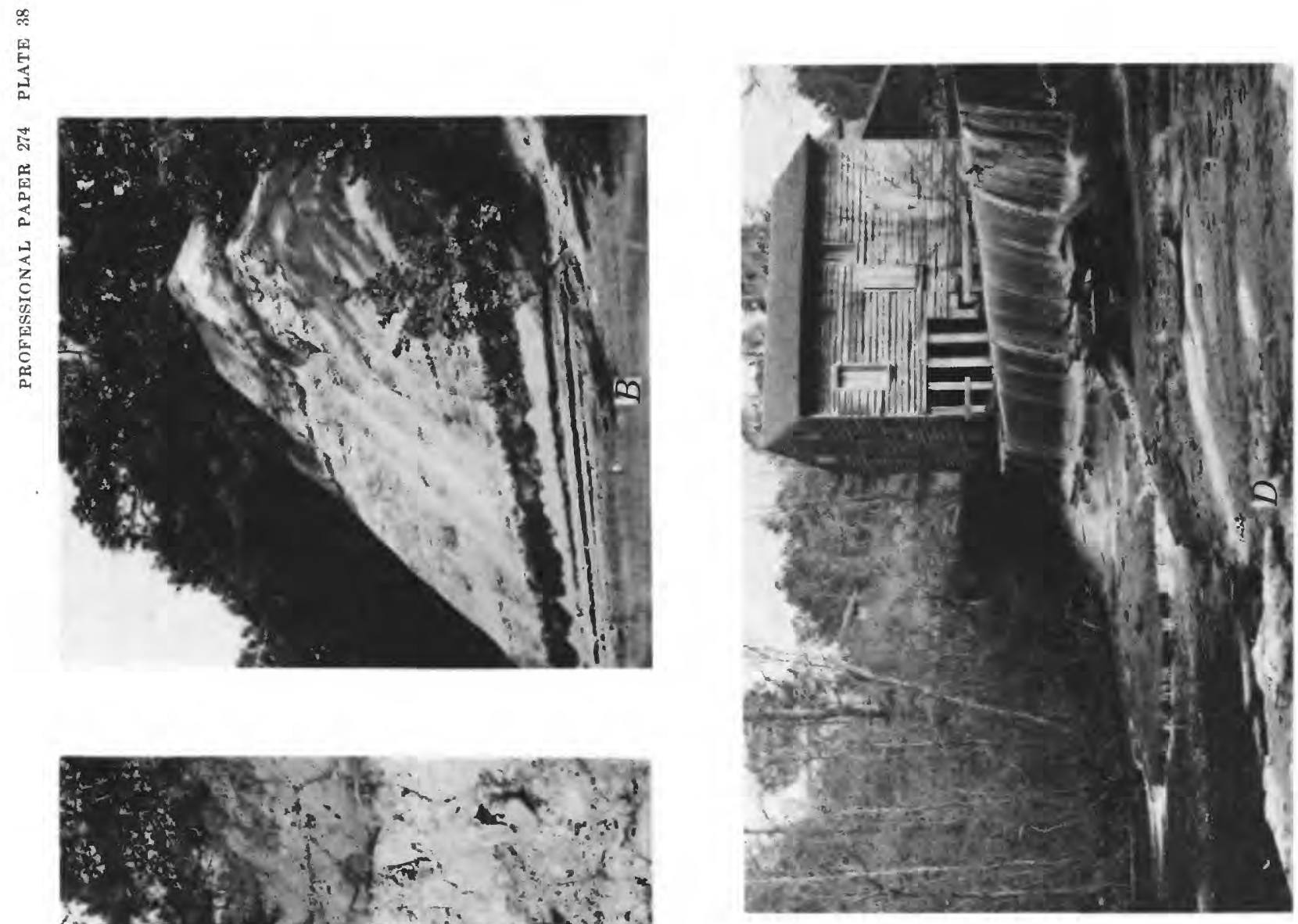

告

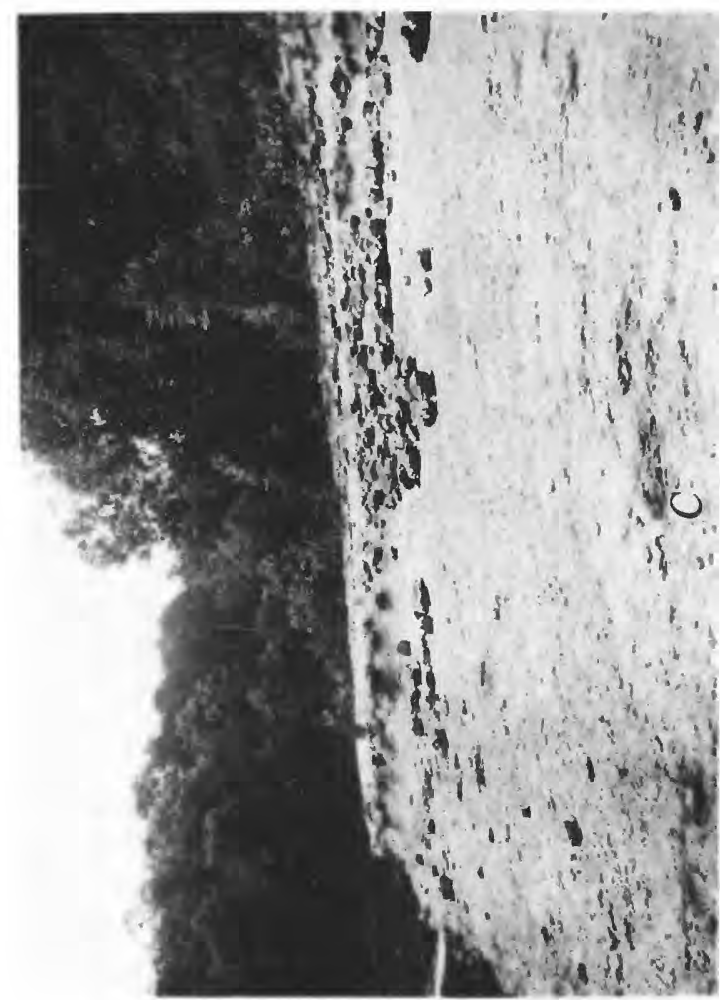




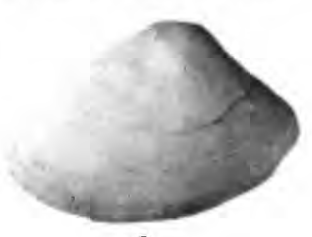

1
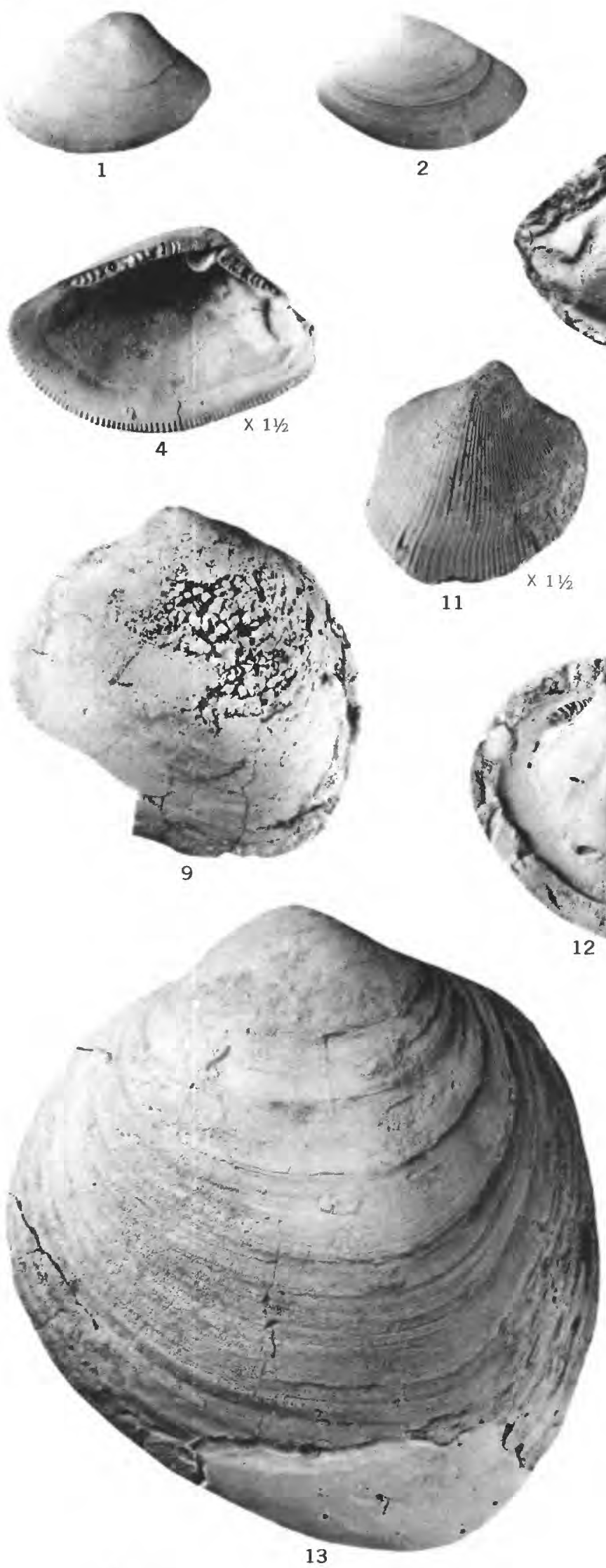
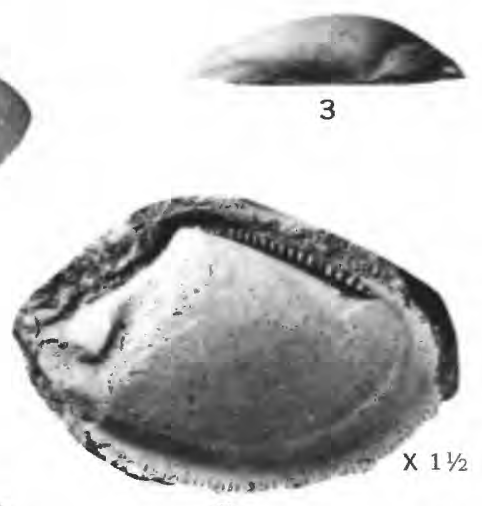

5
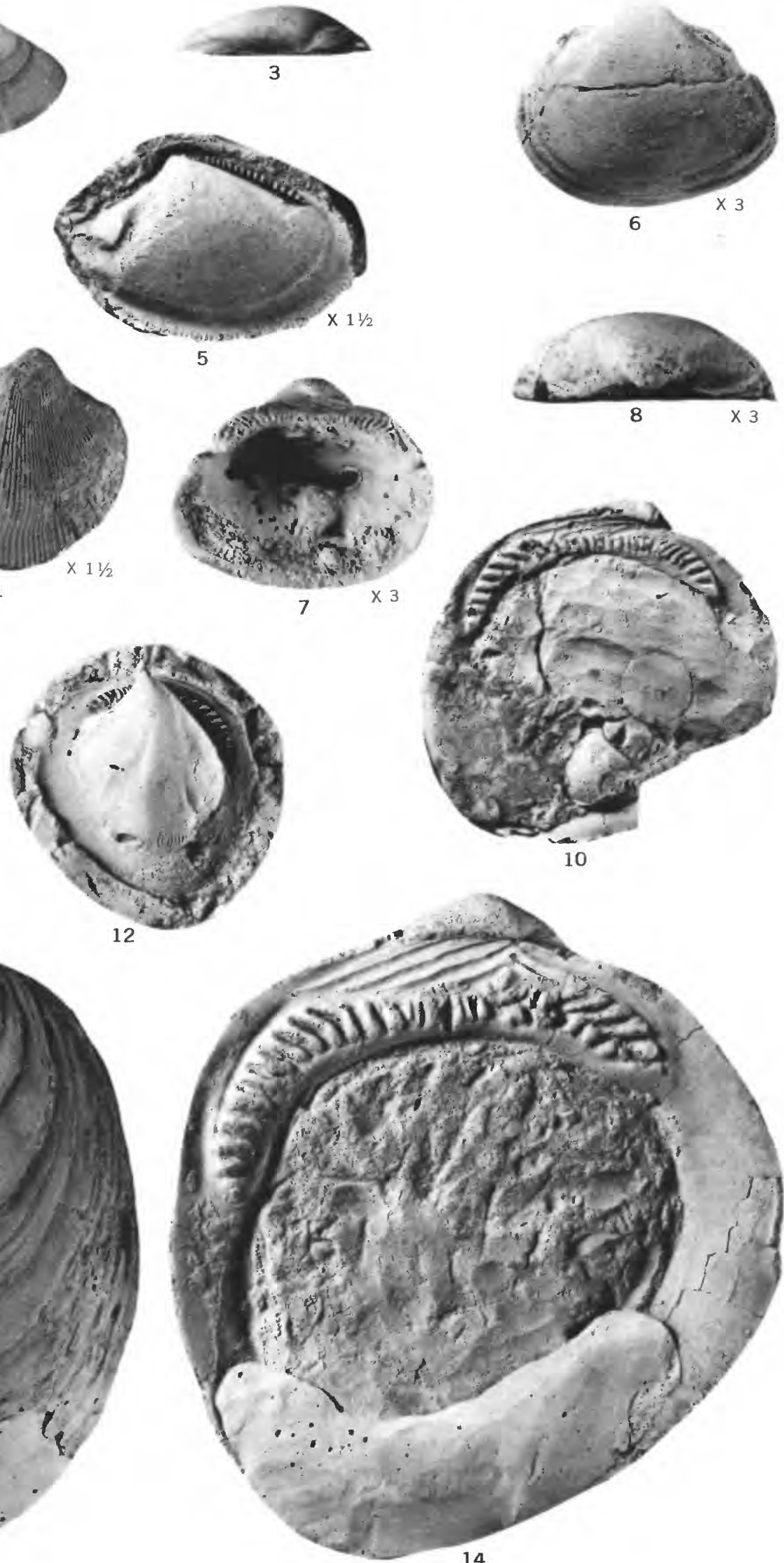


\section{PLATE 39}

[Figures natural size except as indicated]

Figures 1-5. Nucula prepercrassa Stephenson, n. sp. (p. 234).

1. Left valve of a paratype. USGS 15501, USNM 125059.

2, 3. Side and top views of the holotype, a right valve. USGS 15501, USNM 125058.

4. Interior view, $\times 1 \frac{1}{2}$, of holotype.

5. Internal mold, $\times 1 \frac{11}{2}$, of a paratype, a right valve. USGS 5378, USNM 125061.

6-8. Breviarca subinflata Stephenson, n. sp. (p. 236).

Views, $\times 3$, of the holotype, a left valve. USGS 15501, USNM 125067.

9-14. Protarca obliqua Stephenson (p. 235).

9, 10. Exterior and interior views of a plesiotype, a left valve. USGS 15501, USNM 125064.

11. Exterior view, $\times 1 \frac{1}{2}$, of a plesiotype, a young right valve. USGS 5378, USNM 125063.

12. Internal mold of a plesiotype, a left valve, from the same source. USNM 125063.

13, 14. Views of a large plesiotype, a left valve, from the Cusseta sand near Peachburg, Ala. USGS 25478, USNM 125062. (Inserted for comparisor.) 


\section{PLATE 40}

[Figures natural size except as indicated]

Figures 1, 2. Breviarca symmetros Stephenson, n. sp. (p. 236).

Views, $\times 3$, of the bolotype, a left valve. USGs 25567, USNM 125070.

3. Breviarca? sp.

View of left valve, $\times 3$. USGS 15501, USNM 125072.

4-8. Trigonarca inflata Stephenson, n. sp. (p. 237).

4. A paratype, a juvenile right valve. USGS 25567, USNM 125074.

5. Interior view, $\times 2$, of the preceding shell.

6-8. Views of the holotype, a left valve. USGS 25567, USNM 125073.

9, 10. Pseudoptera securiformis Stephenson, n. sp. (p. 238).

9. The holotype, a left valve. USGS 15501, USNM 125076.

10. A paratype, a left valve, mechanically deformed, showing details of sculpture. USGS 25570, USNM 125082.

11, 12. Ostrea cretacea Morton (p. 239).

11. Interior view of a plesiotype, a left valve. USGS 17007, USNM 125027.

12. Exterior view, $\times 1 \frac{1}{2}$, of a left valve, uncoated to show color bands. USGS 18308, USNM 125029. 
GEOLOGICAL SURVEY

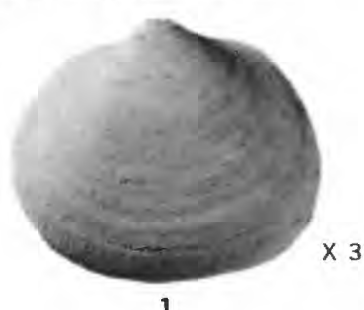

1

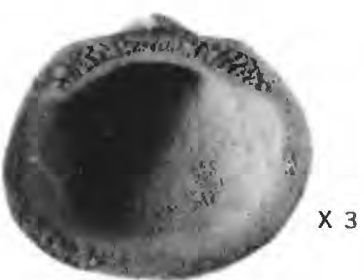

2

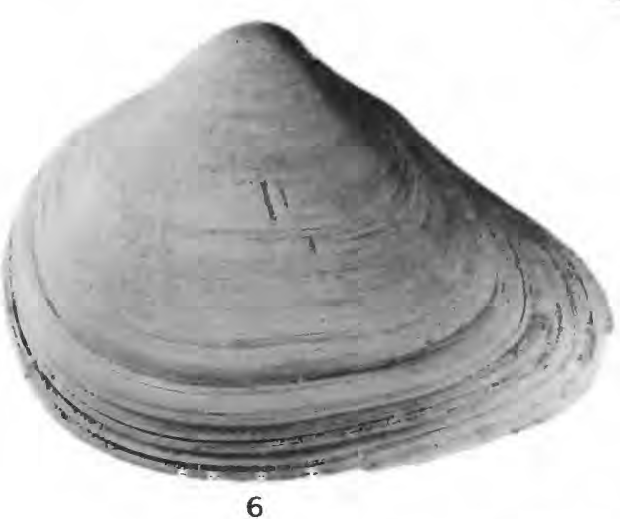

5

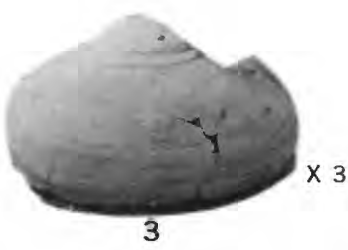

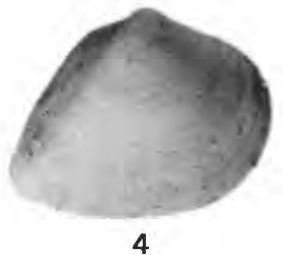

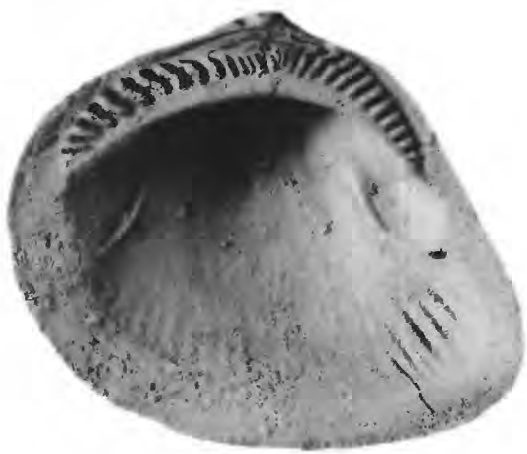

$\times 2$
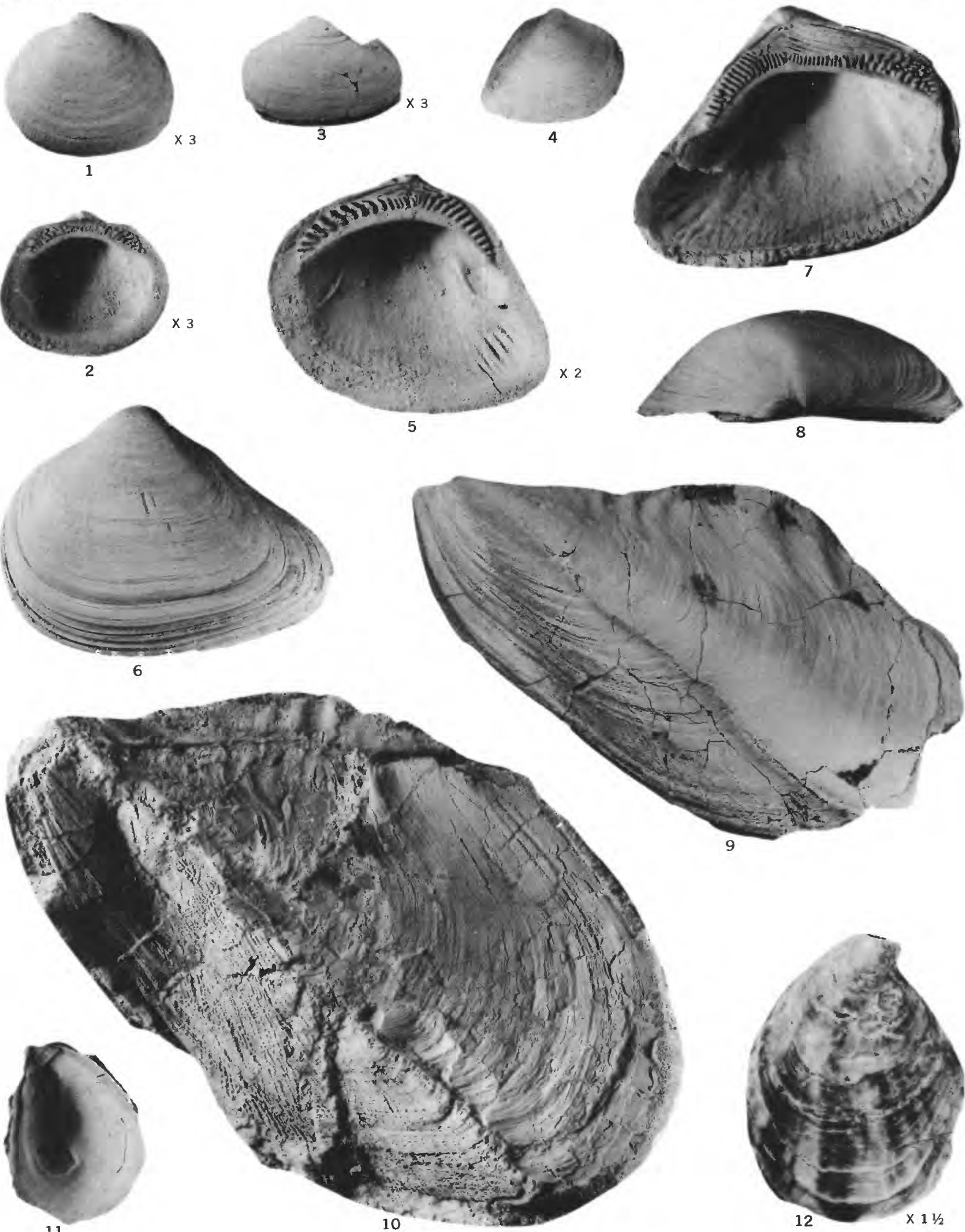
GEOLOGICAL SURVEY

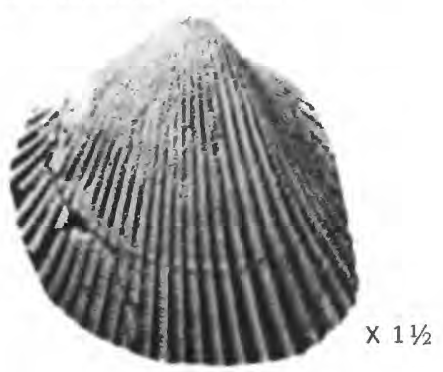

1

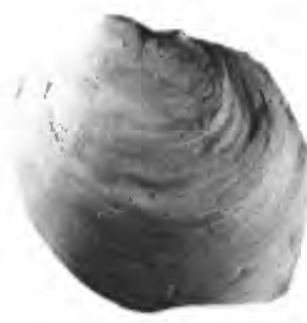

5

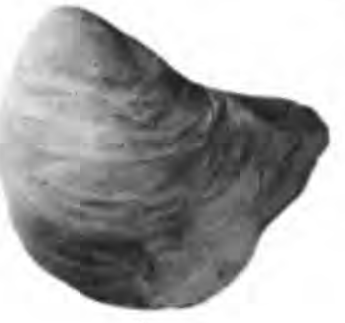

4

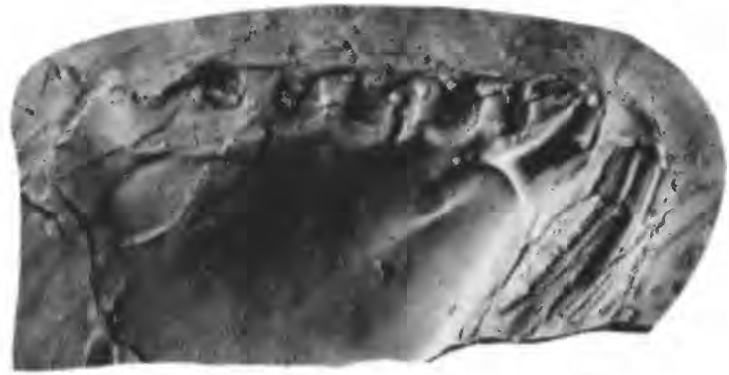

12

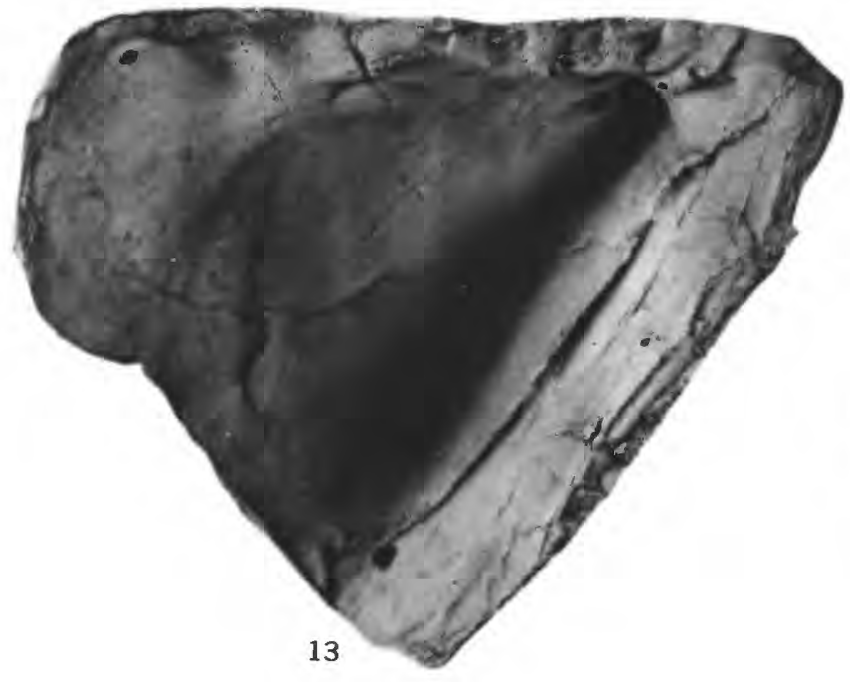

2

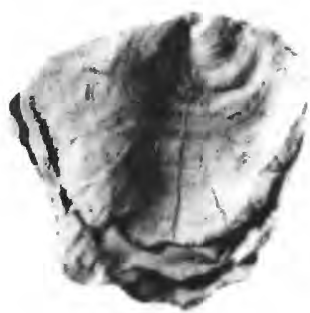

6$$
\text { . }
$$
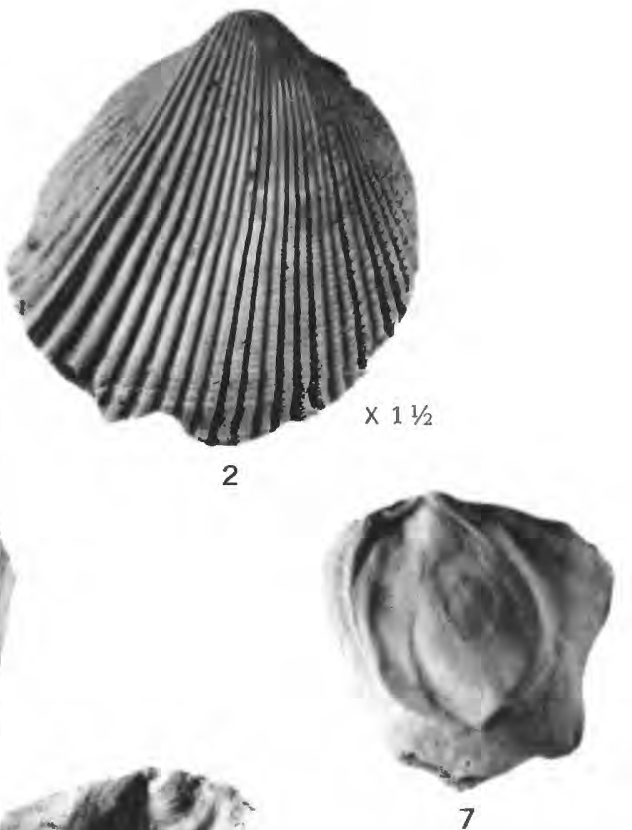

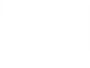




\section{PLATE 41}

[Figures natural size except as indicated]

Figures 1, 2. Cardium (Trachycardium) ochilleanum Stephenson, n. sp. (p. 242).

1. View, $\times 1 \frac{1}{2}$, of a paratype, a left valve. USGS 15501, USNM 125012.

2. View, $X 1 \frac{1}{2}$, of the holotype, a right valve. USGS 15501 , USNM 125010.

3-8. Gryphaea wratheri Stephenson (p. 240).

3. Left valve of a large plesiotype. USGS 6442-B, USNM 125024.

4. Left valve of a plesiotype, showing a posterior wing extension. USGS 19060, USNM 125022.

5. Left valve of a plesiotype lacking posterior wing extension. USGS 17576, USNM 125023.

6. Right valve of a plesiotype from the same source. USNM 125023.

7. Interior view of the preceding shell.

8. Interior view of the shell shown in fig. 5 .

9-11. Anomia preolmstedi Stephenson, n. sp. (p. 242).

9. Exterior of holotype, a left valve. USGS 6409, USNM 125014.

10, 11. Exterior and interior views of a paratype from the same source; the interior view shows the imprint of the byssal opening (foramen) of the right valve on matrix filling. USNM 125015.

12-14. Pseudoptera securiformis Stephenson, n. sp. (p. 238).

12, 13. Rubber casts from internal molds (paratypes) of left valves, showing hinge areas. USGS 5384, USNM 125081.

14. Right side of internal mold (a paratype), showing flattish form of right valve. USGS 5377, USNM 125080. 


\section{PLA'TE 42}

Figures 1-17. Ostrea cretacea Morton (p. 239).

All figures natural size]

1-2. Topotypes, left valves, from Erie Bluff, Warrior River, Ala. USGS 6428, USNM 125026.

3, 4. Plesiotypes (essentially topotypes), from Choctaw Bluff, Warrior River, Ala. USGS 6425, USNM 125025.

5-17. Plesiotypes-arranged to show gradation in dorsal outline from pointed in figure 5 to squarish in figure 17. Figures 5, 13, 4.1 miles north of Creek Stand, Macon County, Ala., USGS 17007, USNM 125027; figures 6, 8-12, 14-16, from 3.1 miles north of Creek Stand, USGS 17006, USNM 125028; figures 7, 17, one-half mile below Broken Arrow Bend, Chattahoochee River, left bank, USGS 5385, USNM 125030. Figures 1-14 are left valves; figures 8,9 are views of left and right valves of same shell; figures 15, 16 are exterior and interior views of a right valve; and figure 17 is a view of right valve. 
GEOLOGICAL SURVEY

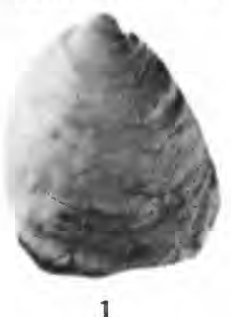

1

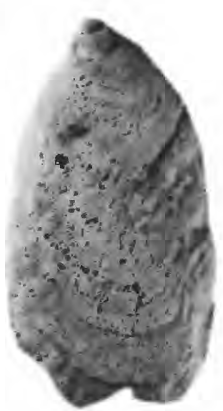

2

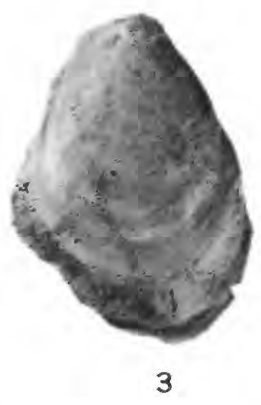

3

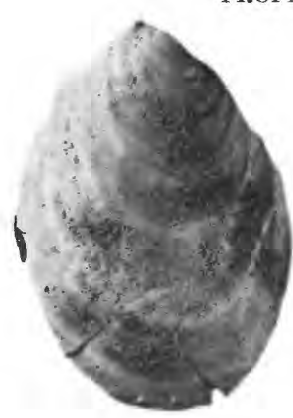

4

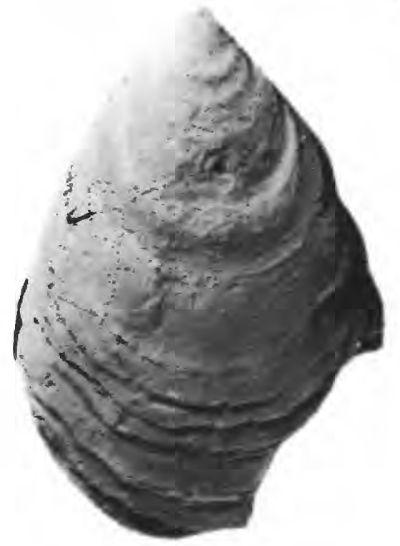

6

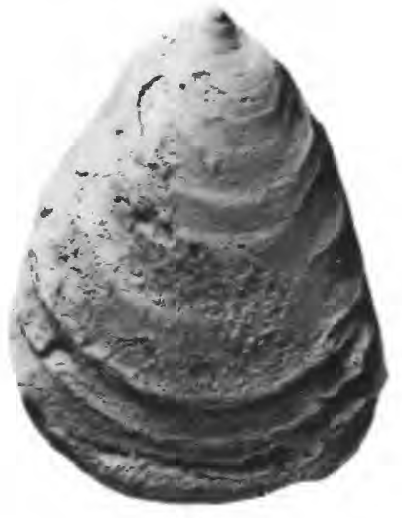

10

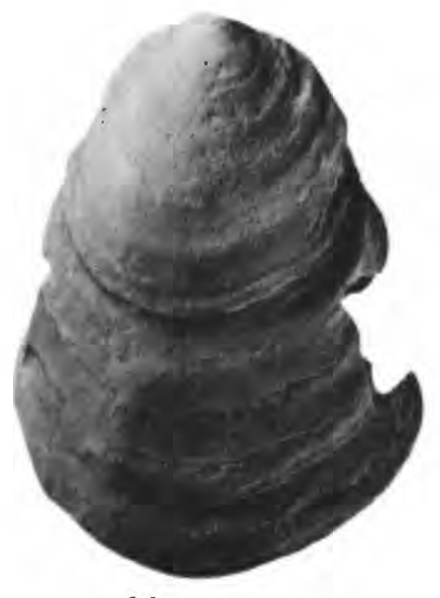

14
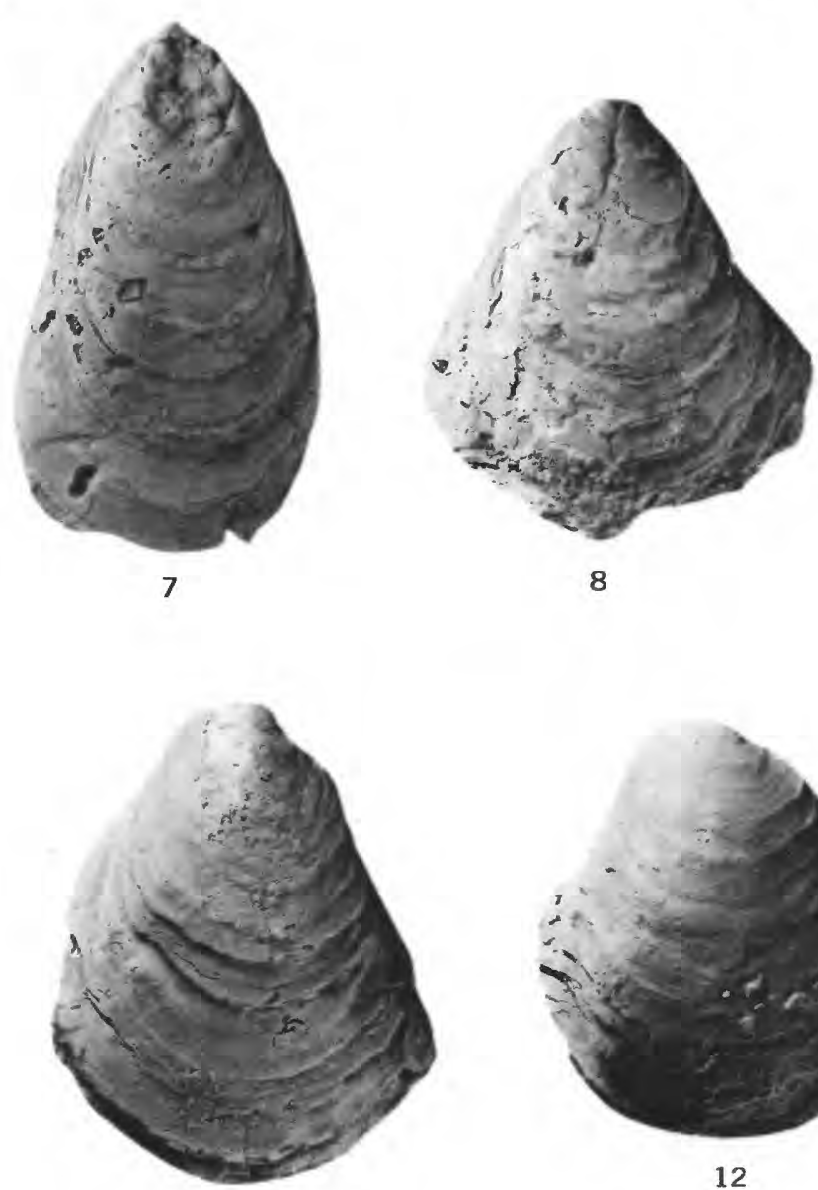

11

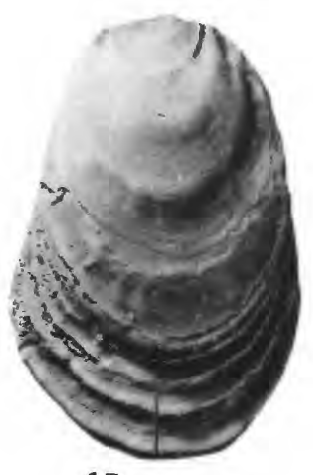

15
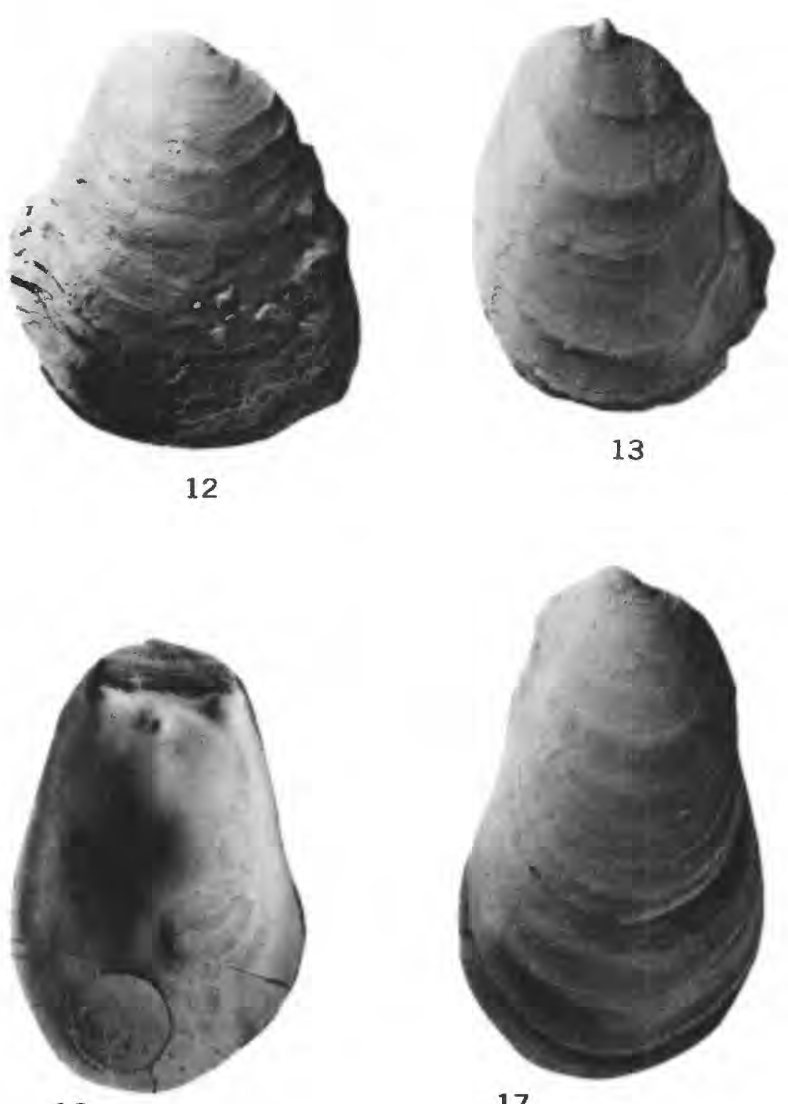

16

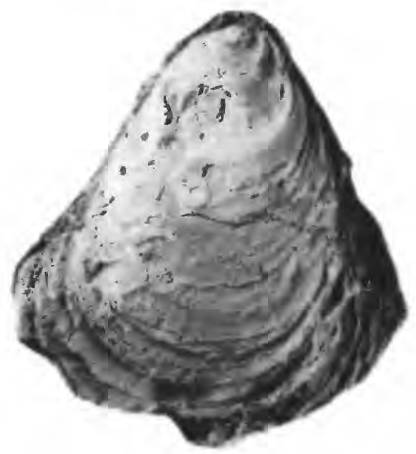

9

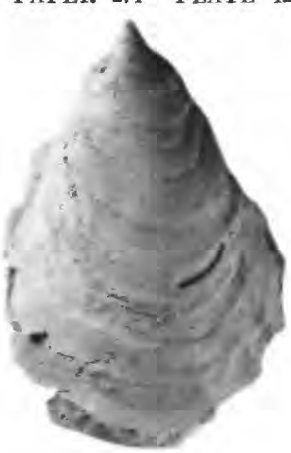

5

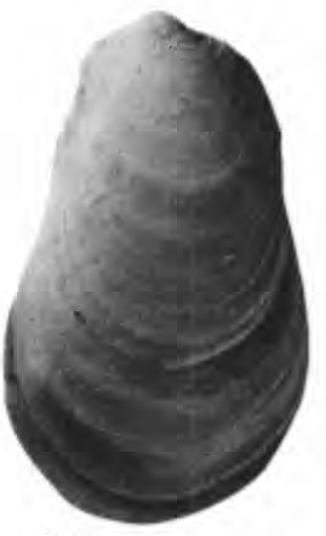

17 

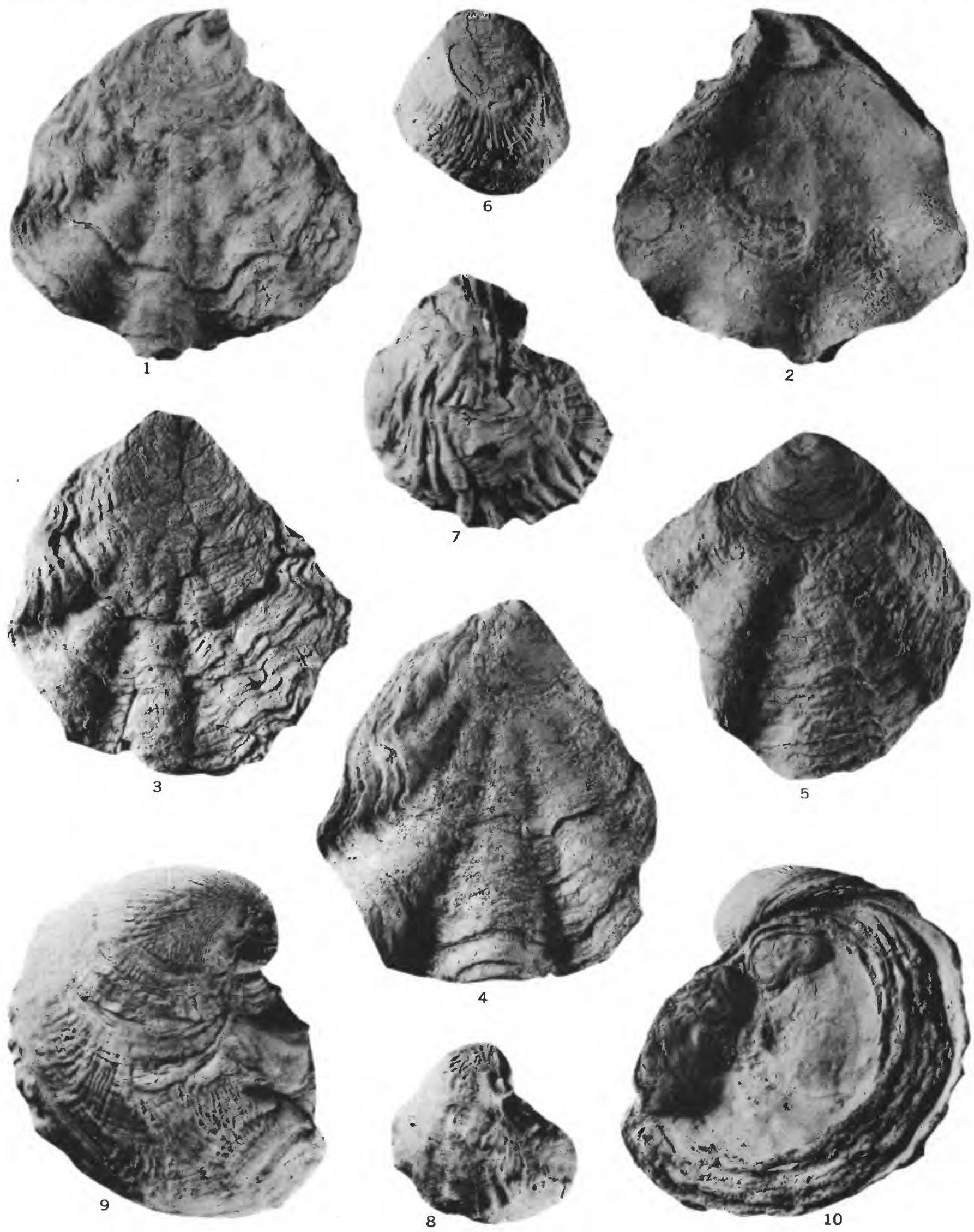


\section{PLATE 43}

[All figures natural size

Figures 1-5. Ostrea (Lopha) ucheensis Stephenson, n. sp. (p. 238).

1, 2. Exterior and interior views of holotype, USGS 17583, USNM 125031.

3-5. Views of 3 paratypes, USGS 18317, USNM 125033.

6-10. Exogyra upatoiensis Stephenson (p. 241).

6. Left valve from Catoma Creek, 5 or 6 miles southwest of Montgomery, Ala., USGS 17010, USNM 125020.

7. Left valve from three-fourths mile north by east of Liberty Hill Church, Macon County, Ala., USGS 17576, USNM 125019.

8. Left valve from 21/4 miles north-northwest of Warrior Stand, Macon County, Ala., USGS 18306, USN M 125018. 9,10 . Views of a large shell, from base of Mooreville chalk, Choctaw Bluff, Warrior River, Greene County, Ala., USGS 25466, USNM 125021. 


\section{PLATE 44}

[Figures natural size except as indicated]

Figdres 1-3. Cymbophora ochilleana Stephenson, n. sp. (p. 244).

1. View, $\times 1 \frac{1}{2}$, of holotype, a right valve. USGS 15501, USNM 125000.

2. View, $\times 11 \frac{1}{2}$, of a paratype, a left valve. USGS 5378, USNM 125004.

3. View, $\times 1 \frac{1}{2}$, of hinge of a paratype, a right valve. USGS 5374, USNM 125002.

4-9. Caryocorbula? veatchi Stephenson, n. sp. (p. 245).

4, 5. Right side and dorsal views, $\times 1 \frac{1}{2}$, of holotype. USGS 5374, USNM 125036.

6, 7. Right side and interior views, $\times 1 \frac{11}{2}$, of a paratype. USGS 15501 , USNM 125038.

8, 9. Exterior and interior views, $\times 1 \frac{1}{2}$, of a paratype, USGS 15501, USNM 125038.

10-13. Caryocorbula? veatchi longa Stephenson, n, var. (p. 246).

10, 11. Exterior and interior views, $\times 1 \frac{112}{2}$ of holotype. USGS 25567, USNM 125041.

12, 13. Exterior and interior views, $X 11 \frac{1}{2}$, of a paratype from the same source. USNM 125042.

14-16. Caryocorbula? georgiana Stephenson, n. sp. (p. 246).

14. View, $\times 1 \frac{1}{2}$, of holotype, a right valve. USGS 15501, USNM 125044.

15. Interior view, $\times 1 \frac{112}{2}$, of a paratype from the same source. USNM 125045.

16. View, $X 1 \frac{112}{2}$, of a rubber cast from internal mold of a left valve. USGS 5378, USNM 125046.

17-20. Legumen aff. L. carolinense (Conrad), (p. 243).

17-18. Right side and dorsal views of an internal mold. USGS 6408, USNM 125006.

19. Left side of an internal mold (uncoated) to show pallial line and sinus. USGS 5377, USNM 125007.

20. Imprint of exterior of a left valve to show concentric markings. USGS 848, USNM 125008.

21, 22. Placenticeras benningi Stephenson, n. sp. (p. 247).

21. Lateral view of a young paratype. USGS 5377, USNM 125050.

22. Lateral view of a young paratype. USGS 15501, USNM 125051. 
GEOLOGICAL SURVEY
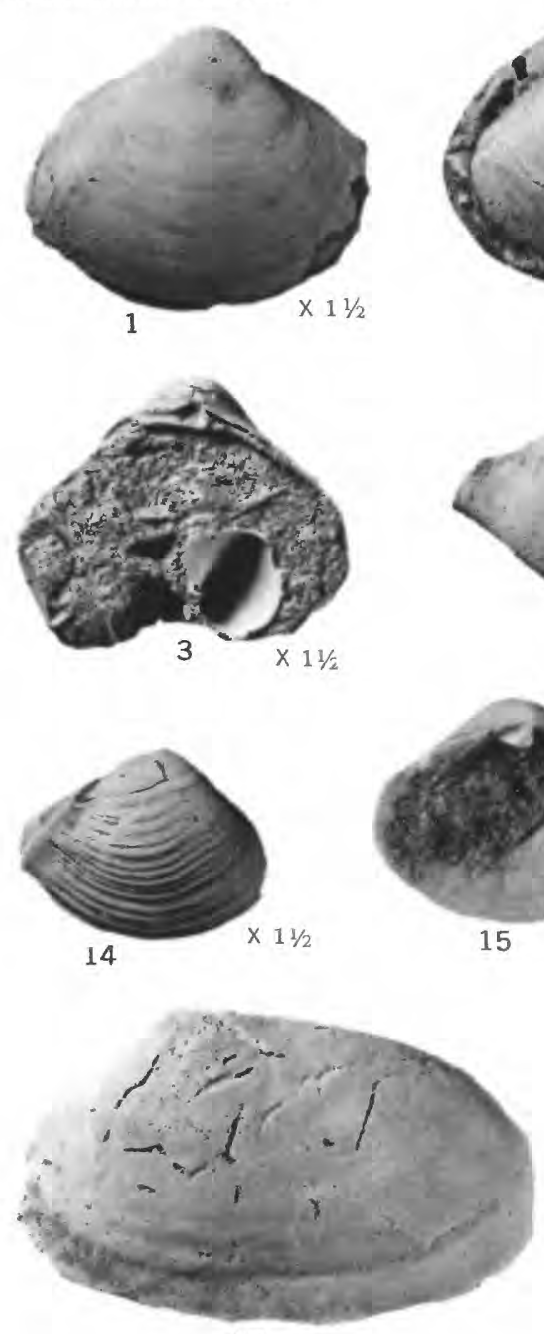

17

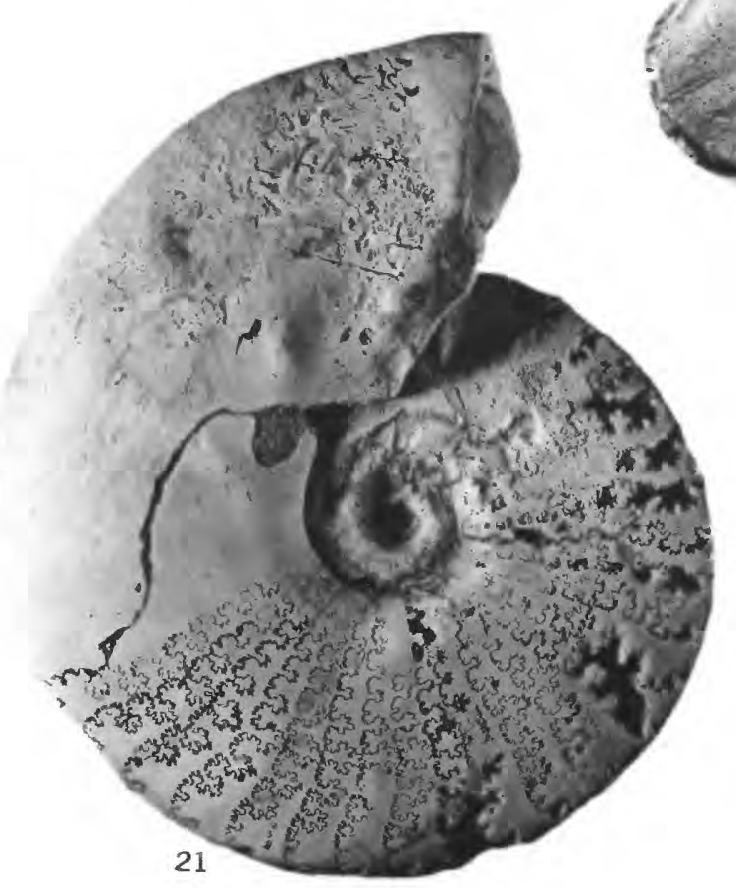

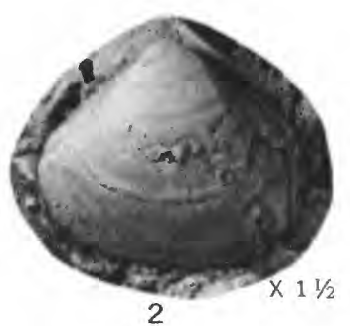
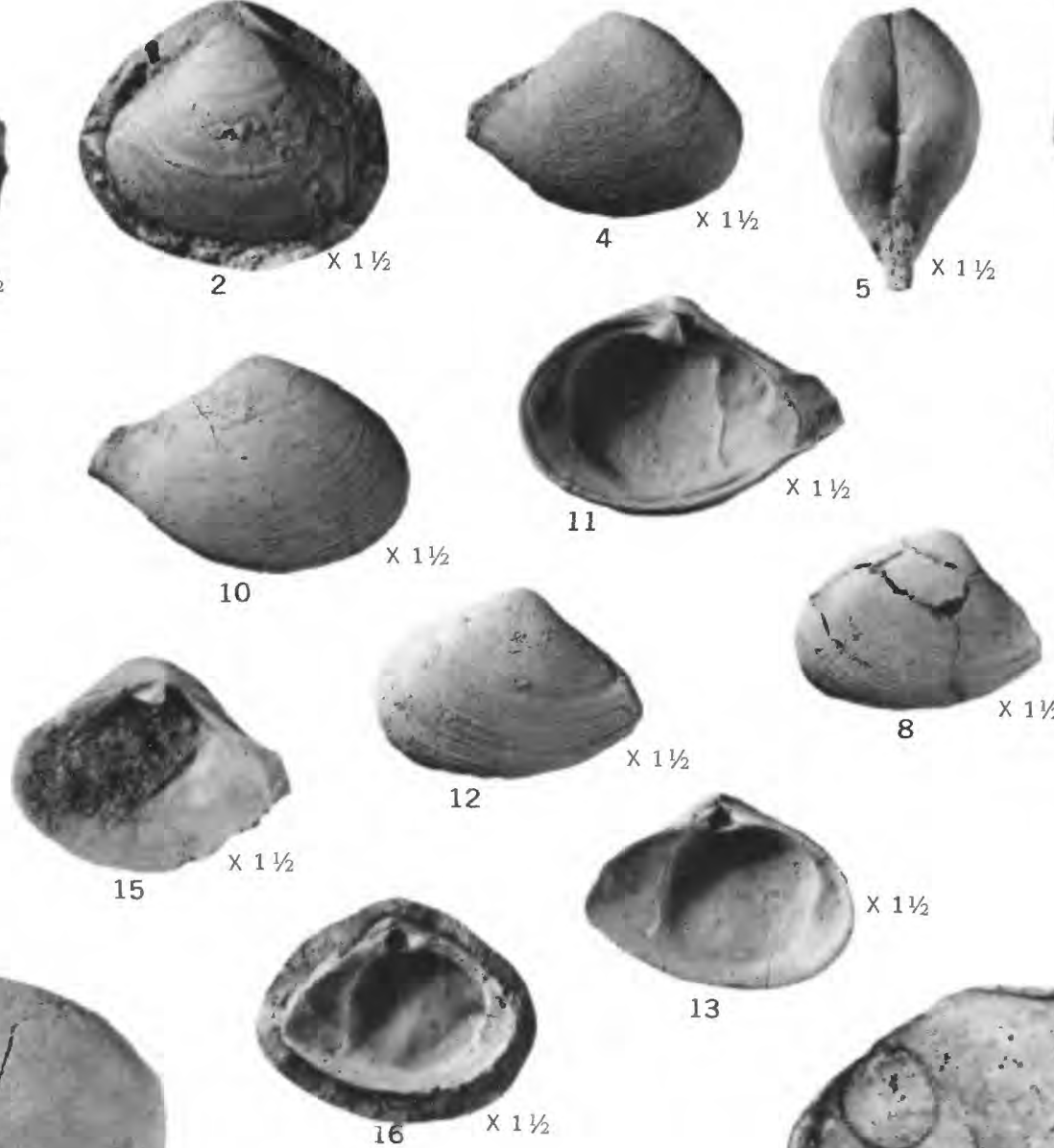

$\times 1 \frac{1}{2}$
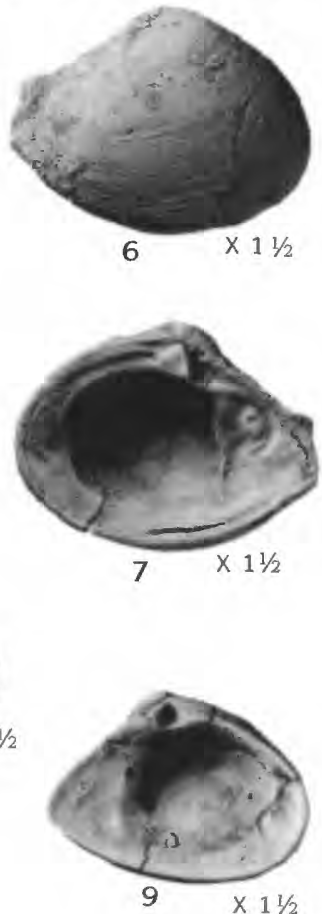

$11 / 2$
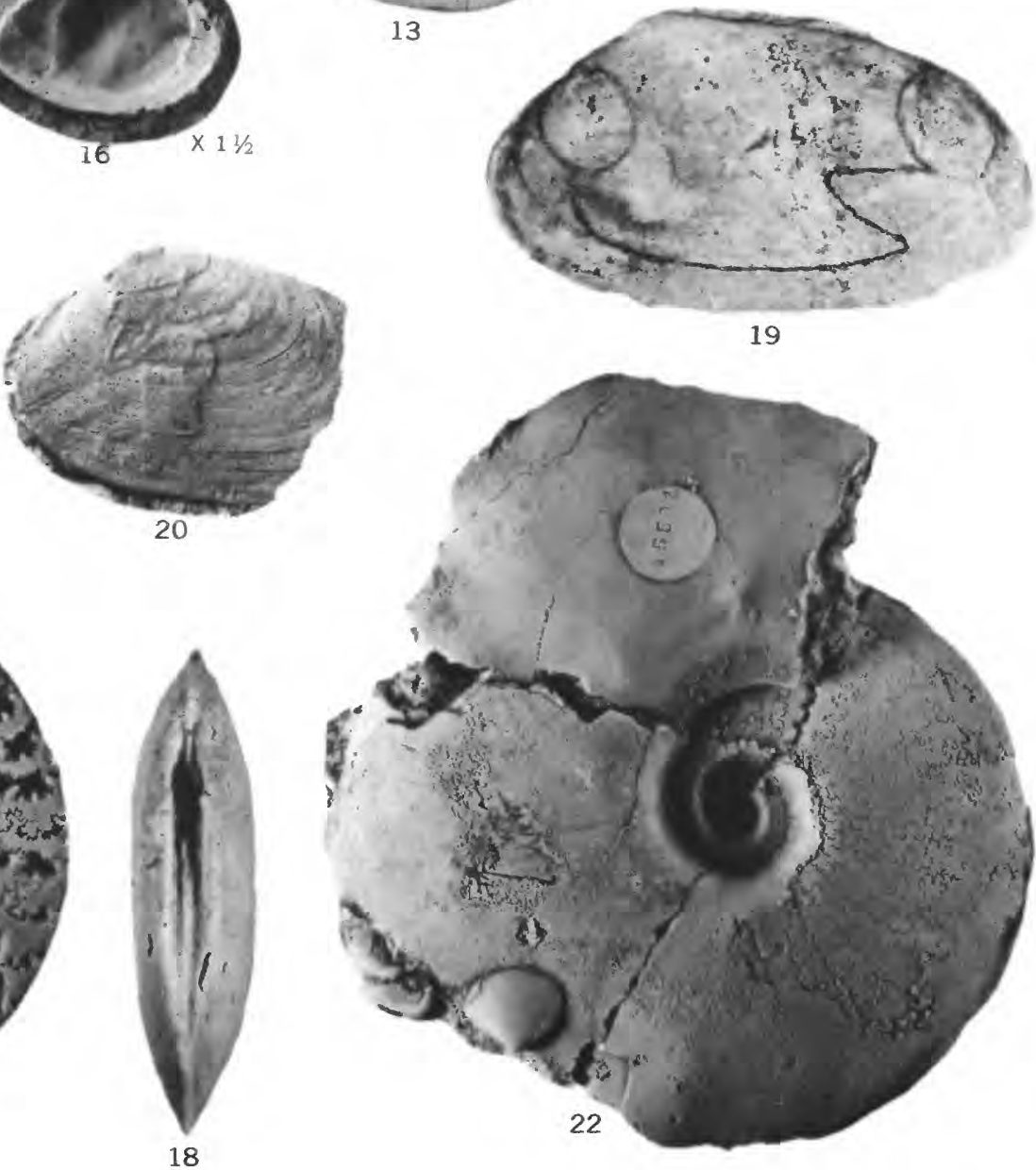


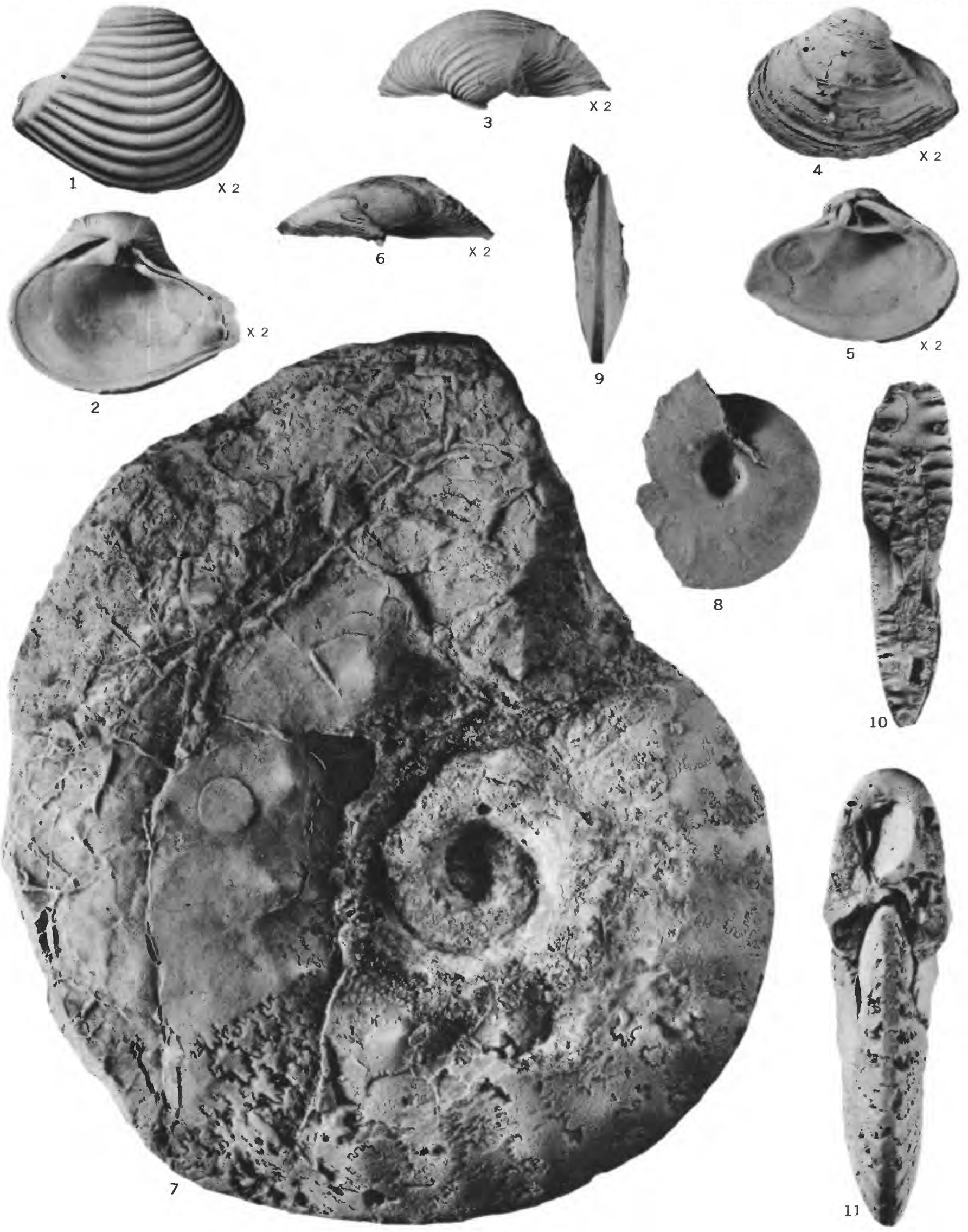




\section{PLATE 45}

[Figures natural size except as indicated]

Figures 1-6. Corbula sulcata Lamarck, inserted for comparison with Cretaceous shells (p. 245).

1-3. Views, $\times 2$, of a Recent right valve, a topotype, from the coast of Senegal, West Africa (USNM Ter. Coll. Moll. 614185).

4-6. Views, $\times 2$, of a left valve, a topotype, from the same collection.

7-11. Placenticeras benningi Stephenson, n. sp. (p. 247).

7. Side view of the holotype. USGS 5384, USNM 125049.

8, 9. Side and front-edge views of a young paratype; note the slightly excavated ventral band. USGS 15501, USNM 125051.

10. View of inner cross section of the paratype shown in plate 44, figure 22, at a diameter of about 65 mm. USGS 15501, USN M 125051.

11. Front ventral view of the paratype shown in plate 44, figure 21 . 